\title{
Deep Underground Injection of Waste from Drilling Activities-An Overview
}

\author{
Nediljka Gaurina-Međimurec ${ }^{(}$, Borivoje Pašić * ${ }^{\mathbb{D}}$, Petar Mijić $\left.{ }^{(}\right)$and Igor Medved \\ Faculty of Mining, Geology and Petroleum Engineering, University of Zagreb, 10000 Zagreb, Croatia; \\ ngaumed@rgn.hr (N.G.-M.); petar.mijic@rgn.hr (P.M.); igor.medved@rgn.hr (I.M.) \\ * Correspondence: borivoje.pasic@rgn.hr; Tel.: +385-1-553-58-40
}

Received: 29 February 2020; Accepted: 25 March 2020; Published: 27 March 2020

\begin{abstract}
Oil and gas exploration and production activities generate large amounts of waste material, especially during well drilling and completion activities. Waste material from drilling activities to the greatest extent consists of drilled cuttings and used drilling mud with a smaller portion of other materials (wastewater, produced hydrocarbons during well testing, spent stimulation fluid, etc.). Nowadays, growing concerns for environmental protections and new strict regulations encourage companies to improve methods for the reduction of waste material, as well as improve existing and develop new waste disposal methods that are more environmentally friendly and safer from the aspect of human health. The main advantages of the waste injection method into suitable deep geological formations over other waste disposal methods (biodegradation, thermal treatment, etc.) are minimizing potentially harmful impacts on groundwater, reducing the required surface area for waste disposal, reducing the negative impact on the air and long-term risks for the entire environment. This paper gives a comprehensive overview of the underground waste injection technology, criteria for the selection of the injection zone and methods required for process monitoring, as well as a comprehensive literature overview of significant past or ongoing projects from all over the world.
\end{abstract}

Keywords: drilling waste; injection pressure; waste slurry; drilled cuttings; injection methods and equipment; disposal zone; waste containment; process monitoring; rock fracturing

\section{Introduction}

Oil and gas industry through exploration and production (E\&P) activities generate large amounts of different waste through several different processes, including wellbore drilling, well completion and workover, reservoir stimulation (fracturing and acidizing) and hydrocarbons production, as well as transporting and storage of hydrocarbons and associated products (carbon dioxide, produced/wastewater, etc.). Drilling activities on their own generate the second largest amount of waste, following reservoir water produced during oil and gas production [1-4]. Nowadays, probably the largest amounts of waste during oil and gas E\&P activities are generated during the development of unconventional reservoirs, because large amounts of water are required for reservoir stimulation through the massive fracturing of reservoir rock.

Waste that is generated through drilling activities primarily consists of spent drilling fluids and drilling cuttings. The main components of waste generated through drilling activities are listed in Table 1, as well as their significant constituents that can affect the environment. Despite a certain portion of environmentally harmful constituents such as heavy metals, radioactive materials or organic salts, waste from drilling, as well as waste from other exploration and production activities in the United States of America, are classified as nonhazardous waste according to US regulations [5]. However, it is important to note that classification of the waste from oil and gas exploration and production activities (including waste from drilling activities) depends on the state or country regulations and regulatory 
requirements, as well as on its composition. In the European Union, drilling waste injection is a waste disposal method defined by the EU Waste Framework Directive 2008/98 (Disposal Operations: D3 Deep injection).

Table 1. Composition of waste generated through drilling activities [1].

\begin{tabular}{|c|c|c|}
\hline Type of Waste & Main Components & $\begin{array}{l}\text { Possible Environmentally } \\
\text { Significant Constituents }\end{array}$ \\
\hline Waste lubricants & Lube oil, grase & Heavy metals, organics \\
\hline Spacers & Mineral oil, detergents, surfactants & Hydrocarbon, alcohol, aromatics \\
\hline $\begin{array}{l}\text { Spent/contaminated water-based } \\
\text { muds (include brine) }\end{array}$ & $\begin{array}{l}\text { Whole mud, mineral oil, } \\
\text { biodegradable matters }\end{array}$ & $\begin{array}{l}\text { Heavy metals, inorganic salts, biocides, } \\
\text { hydrocarbons, solids/cuttings, organics }\end{array}$ \\
\hline Waste-based mud cuttings & $\begin{array}{l}\text { Formation solids, water-based } \\
\text { muds, mineral oil }\end{array}$ & $\begin{array}{c}\text { Heavy metals, inorganic salts, biocides, } \\
\text { hydrocarbons, solids/cuttings }\end{array}$ \\
\hline $\begin{array}{l}\text { Spent/contaminated } \\
\text { oil-based muds }\end{array}$ & Whole-mud mineral oils & $\begin{array}{l}\text { Hydrocarbons, heavy metals, inorganic } \\
\text { salts, solids, organics, surfactants }\end{array}$ \\
\hline Oil-based mud cuttings & $\begin{array}{l}\text { Formation solids, } \\
\text { oil-based muds }\end{array}$ & $\begin{array}{l}\text { Heavy metals, inorganic salt, } \\
\text { hydrocarbons, solids/cuttings }\end{array}$ \\
\hline Spent bulk chemical & $\begin{array}{l}\text { Cement, bentonite, barite, } \\
\text { viscosifiers, thinners, fluid loss } \\
\text { reducers, special products }\end{array}$ & $\begin{array}{l}\text { Heavy metals, hydrocarbon, } \\
\text { organics, solids }\end{array}$ \\
\hline Spent special products & $\begin{array}{c}\mathrm{H}_{2} \mathrm{~S} \text { scavengers, defoamers, } \\
\text { tracers }\end{array}$ & $\begin{array}{l}\text { Zinc carbonates, iron oxides, } \\
\text { hydrocarbons, silicon oils, potassium } \\
\text { salts, radioactive materials }\end{array}$ \\
\hline
\end{tabular}

Additionally, it is important to emphasize that drilling activities generate several times more volumes of waste in comparison with volumes of the drilled hole. The reasons for this are numerous, such as changes and modifications of drilling fluids in accordance with the requirements of the drilling program, the impossibility of removing all drilling cuttings from the drilling fluid, etc. Sometimes, drilling a shallow well results in large quantities of waste potentially more dangerous to the environment than in the case of drilling much deeper wells, even though the water-based mud was used. In the 1990s, a large number of shallow horizontal wells were drilled in Eastern Venezuela to produce very heavy oil, and during the drilling, the majority of the waste generated was contaminated with up to $20 \%$ of crude oil because a large horizontal section was drilled through the reservoir [6]. The quantity and composition of waste generated by the oil and gas industry greatly depends on specific activities each year. In 1994, 75\% of all waste generated by the exploration and production activities of the Amoco Production Corporation was the result of drilling activities, with an average of $700 \mathrm{~kg}$ of drilling waste per meter of the drilled hole [7]. A year later, the American Petroleum Institute estimated that almost 24 million cubic meters of waste were generated in 1995 solely during drilling onshore wells in the United States of America [8]. Nowadays, oil and gas companies generate smaller quantities of waste during drilling activities for the same drilled volume of the rock in comparison to the past because of the implementation of the smart waste management strategy during the field development planning phase.

\section{Overview of Oil and Gas Exploration and Production Waste Disposal Methods}

Historically, waste generated by drilling activities has been disposed using the most accessible and cost-effective methods available to the operators, which resulted in the disposal of large amounts of drilling waste in reserve pits [9]. Depending on the particular technology, the disadvantages of various surface methods for the treatment of waste generated by drilling activities (solidification, bioremediation, incineration or different chemical and mechanical treatments) are: the need for large storage capacities, production of the residual material after treatment, need for a large land area for treatment and high cost [10-12]. At the same time, the evolution of different international and local (country or state) regulations encourages operators to develop waste management systems (strategy) 
providing the greatest possible reduction of waste materials and use disposal methods that are more environmentally friendly and safer for the human health [13,14]. Drilling waste management includes three basic principles: reduction of the waste volume, recycling or reusing and application of specific waste disposal methods whose selection strongly depends on state legislation with the particular reference to future liability $[8,13,15-17]$.

In that sense, the injection of waste from oil and gas explorations and production activities (including waste from drilling activities) into deep subsurface formations as one of the on-site permanent waste disposal methods achieves zero discharge; improves the protection of the groundwater and surface; has a small surface footprint; reduces the need for waste transportation (via pipelines, marine vessels or tankers on-shore) and disposal costs; eliminates risks associated with the surface accumulation of generated waste and is not limited by locations [10,18-24]. Besides all that was mentioned above, subsurface injections of drilling waste makes the continuous use of oil-based mud during drilling troubled shale formations in environmentally sensitive areas possible [25]. Deep underground waste injections (cutting reinjection (CRI) or downhole waste injection (DWI)) are still the most economic methods for the disposal of waste generated through exploration and production activities in comparison with other available waste disposal methods [26,27]. For example, in the period of two years (concluded by March 2000), in Port Fourchon (Louisiana), more than 160,000 $\mathrm{m}^{3}$ of waste produced by drilling and production activities containing naturally occurring radioactive materials (NORM) has been injected into a single well with an average cost of $\$ 119.5$ per cubic meter of waste material, which is far less in comparison with the off-site waste disposal, with an estimated cost of $\$ 629$ per cubic meter of the same waste material [18]. Similar to the previous example, in the period from 1995 to 2004, Marathon Oil Company implemented a waste slurry injection program in the drilling waste management system and achieved an $89 \%$ disposal cost reduction during operations in Alaska (from $\$ 337.3$ to $\$ 36.8$ per cubic meter of waste material) [13]. The quantitative and qualitative comparison of different drilling waste disposal methods is summarized in Table 2. The cost of waste disposal by different commercial methods listed in Table 2 depends on different factors, such as the transportation of waste to the disposal/treatment site, cost of the disposal/treatment process itself and cost of the monitoring process [28].

Table 2. Comparison between different disposal methods for waste from drilling activities [6,29].

\begin{tabular}{|c|c|c|c|c|}
\hline $\begin{array}{l}\text { Comparison } \\
\text { Factor }\end{array}$ & Fixation & $\begin{array}{l}\text { Thermal } \\
\text { Treatment }\end{array}$ & $\begin{array}{l}\text { Drilling Cuttings } \\
\text { Reinjection }\end{array}$ & Bioremediation/Composting \\
\hline $\begin{array}{c}\text { Environmental } \\
\text { impact }\end{array}$ & Low & High & Low & Medium \\
\hline Cost & $\$ 57-63$ per $\mathrm{m}^{3}$ & $\begin{array}{l}\$ 90 \text { per metric ton } \\
\text { (or } \$ 80 \text { per } \mathrm{m}^{3} \text { for } \\
\text { oil-specific gravity } \\
0.88 \text { ) }\end{array}$ & $\$ 31$ per $\mathrm{m}^{3}$ & $\$ 500$ per $\mathrm{m}^{3}$ \\
\hline Cost factor & $\begin{array}{c}\text { May require transport } \\
\text { and liner and requires } \\
\text { monitoring }\end{array}$ & $\begin{array}{l}\text { Requires transport; } \\
\text { air emission control }\end{array}$ & $\begin{array}{l}\text { More expensive if } \\
\text { dedicated well(s) } \\
\text { are required }\end{array}$ & $\begin{array}{l}\text { May require transport and } \\
\text { required monitoring }\end{array}$ \\
\hline Safety risks & High & High & Low & Medium \\
\hline Technical feasibility & Low & Medium & High & Medium \\
\hline Liability & $\begin{array}{l}\text { Liability may be } \\
\text { long-term if there are } \\
\text { subsequent problems } \\
\text { with liner, etc. }\end{array}$ & $\begin{array}{l}\text { Little liability apart } \\
\text { from substances } \\
\text { like heavy metals } \\
\text { remaining in the } \\
\text { cleaned material }\end{array}$ & $\begin{array}{l}\text { Little liability } \\
\text { if performed } \\
\text { correctly }\end{array}$ & $\begin{array}{l}\text { Short-term liability while } \\
\text { material is treated during } \\
\text { biotreatment, or possible } \\
\text { long-term liability if there is } \\
\text { subsequent degradation of } \\
\text { stabilized material (spreading) }\end{array}$ \\
\hline
\end{tabular}

Generally, E\&P companies independently define processing for drilling waste disposal based on waste composition, best available waste disposal methods, best engineering practices and with respect to regulations. There are also different waste materials that are not suitable for deep underground 
injections through the slurry fracture injection, such as materials that react with the formation or generate gas under downhole conditions [6,21].

\section{History of the Drilling Waste Underground Injection}

The first drill cuttings (in the form of waste slurry) underground injection projects started with the injection of small volumes of waste in the annular or tubular wellbore at an offshore drilling project in an environmentally sensitive area. These injection wells were located in the Gulf of Mexico, and such projects began in the mid-1980s [30-34]. After the proven success of such drilling waste disposal projects, similar new projects were carried out in the Gulf of Mexico (Ewing Bank and Fushon); the North Sea (Vallhal, Ekofisk, Ula, Gyda and Clyde); the North Slope in Alaska (Prudhoe and Endicott); Canada (Panuke); Venezuela (Pedernalis); Russian Federation (Sakhalin Islands and Western Siberia); Western Canada and other areas where weather conditions, strict regulations and logistics problems made this method a viable disposal option [19,33,35-37]. During the 1990s, waste slurry injection became a proven method as an environmentally safe and economically viable solution for the disposal of cuttings and other associated waste from oil and gas exploration and production activities (excess drilling fluids, rain water, oily/wash water, displacement pills, storage waste, produced sand, produced sand and gorp from heavy oil "cold production", slop, etc.) into subsurface formations, especially for remote and ecologically sensitive areas [36,38,39]. Some oil and gas exploration and production companies like Conoco Inc. in the early 1990s successfully tried out an annular injection of slurry waste composed of waste wash water; oil-coated drilling cuttings and nonhazardous additional waste generated on drilling rigs, such as glass, paper, pallets, plastics, rope, styrofoam, metal buckets, etc. [40]. Although subsurface injections of waste materials from drilling activities is a well-known and successful technology whose effectiveness has been confirmed through time, there are many challenges, such as frequent changes in regulation, selection of suitable geological formation, monitoring and verification of injection process, design of the whole process, etc. [41].

According to Bruno et al. [22] from Terralog Technologies, one of the leading companies in waste slurry injection technology, there are three main engineering goals in the waste injection project:

- $\quad$ To secure injected waste containment within the desired formation (environmental management).

- To maintain maximum injectivity during the implementation of the project with minimum well workover intervention (cost management).

- $\quad$ To maximize formation storage capacity and well life (asset management).

\section{Injection Methods and Equipment}

The surface process of drilling waste injection consists of collecting cuttings from drilling wells; mixing the cuttings with liquid waste, water and additives to create slurry and injecting the slurry into a selected underground formation through an injection well.

The waste from oil and gas exploration and production can be injected into selected underground formations by applying different methods [11]. The screening process of appropriate waste injection methods represents a crucial part of any successful waste injection project, and it is based on the quantity and quality of available information about the selected underground formation (formation pressure, fracture pressure, permeability, pore throat diameter, etc.); selected injection well (well integrity, completion design, well construction, etc.) and quantity and properties of the waste (volume, chemical composition, rheological properties, solid particle size and content, etc.) [30].

One of the most important steps of waste injection method selection refers to the fracture pressure of the underground formation selected for waste injection. From this standpoint, waste slurry can be injected at a pressure lower than the fracture pressure of the underground formation selected for waste slurry injection (subfracture injection) or at a pressure higher than the fracture pressure (slurry fracture injection). Selection of these two injections methods is based on state regulations, as well as characteristics of the waste slurry and target formation. Until 2000, in the Gulf of Mexico and nearby 
producing region, more than $80 \%$ of drilling waste from offshore and transition zone operations and more than $90 \%$ of nonhazardous oilfield waste from exploration and production activities was disposed in a selected underground formation below the formation fracture pressure [31,42].

During the subfracture waste injection process, the injected waste slurry flows radially from the wellbore and fills the pore space within the selected geological formation. On the other hand, the slurry fracture injection is a more complex process due to the formation of the fractures. In most cases, it is very difficult to predict the geometry of the created fractures and follow their propagation in real time because of the lithology, local stress conditions, mineralogical composition of a selected formation, the existence of natural fractures within, etc.

The waste slurry injection can also be conducted as a continuous injection process or an intermittent injection process $[43,44]$. Unlike the continuous waste injection process, which implies a constant injection of a large quantity of waste slurry, intermittent injection is convenient for a smaller volume of waste slurry, especially in situations where there is a continuous need for process monitoring in order to prevent unwanted problems (pore throat plugging, adverse pressure increase over the formation fracture pressure, development of a large uncontained fracture, etc.).

\subsection{Selection of the Appropriate Waste Injection Method}

From the standpoint of the injection well selection as the conduit for safe slurry waste transportation to the selected underground formation, two main methods for E\&P waste injection are accepted worldwide: tubular injection and annular injection (Figure 1) [30,45,46]. An injection well can be intentionally drilled for drilling waste injection purposes (dedicated wells) or be refitted from its original purpose (converted or redundant wells).
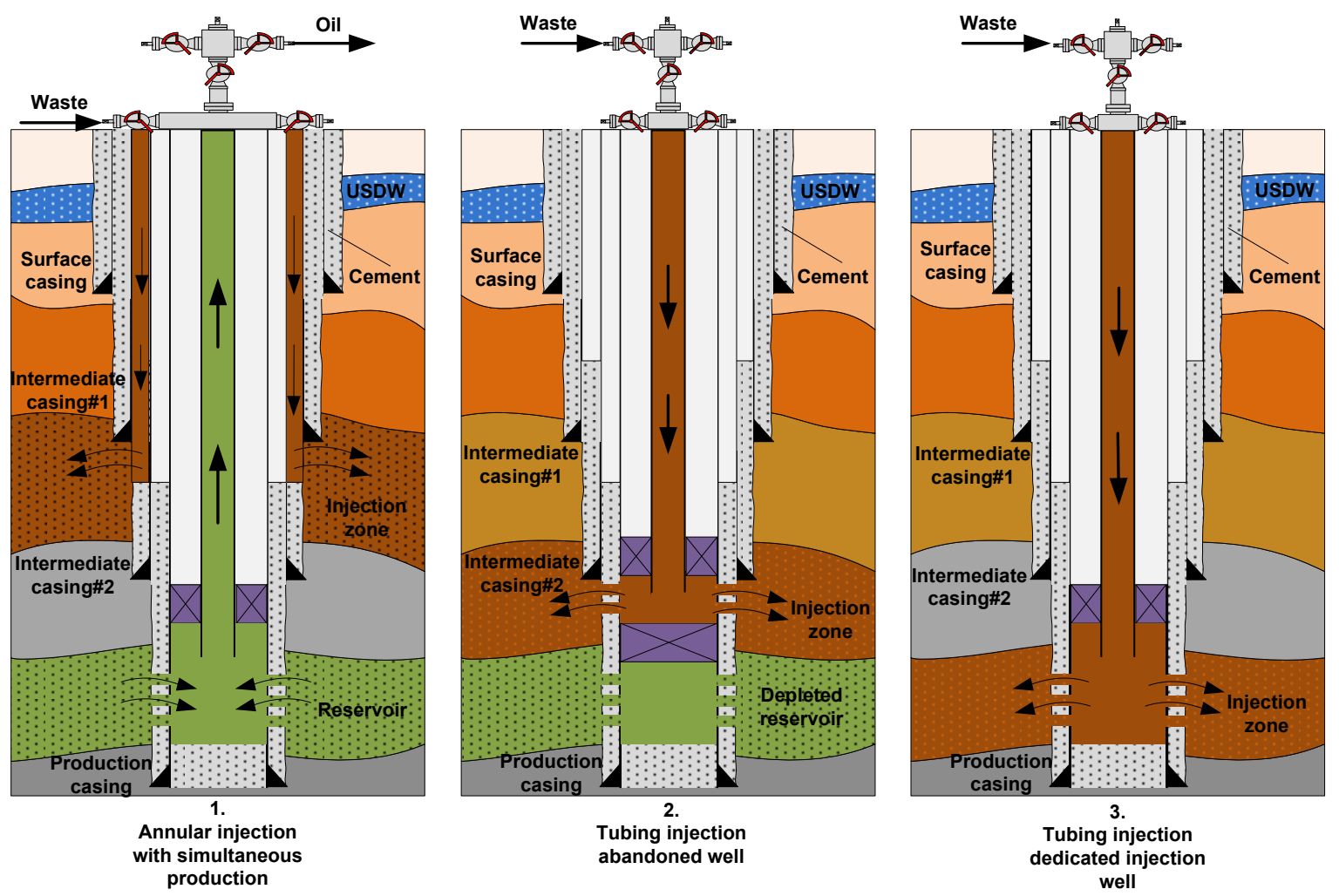

Figure 1. Annular waste injection (1) and tubular injections (2 and 3).

\subsubsection{Annular Injection of Drilling Waste}

In an annular waste injection, usually the liquid phase of the drilling waste is injected into the annular space between two casings strings (usually the surface casing and intermediated casing string), 
while at the same time, the production casing string and tubing may be used for other purposes, e.g., hydrocarbon production (Figure $1(1$.$) ). It allows the disposal of usually liquid drilling waste from the$ well that is being drilled from an adjacent well or the disposal of all waste from drilling pads that have been used for drilling multiple wells in a certain area. The basic prerequisite for this operation is the existence of uncemented annular space between the casings from the surface right until the selected formation (the surface casing string is usually cemented in its entire length and the intermediate casing string only at a certain length from the casing shoe) [47].

The annular drilling waste injection, especially a waste slurry injection above the formation fracture pressure, increases burst loading of the external casing string and collapses the loading of the inner casing string. It also causes wellhead and casing string erosion. Minton and Secoy [48] analyzed the fluid velocity profile during an annular injection, recognized the inner casing hanger opposite to the wing valve on the casing spool as a critical point from an erosion point of view and concluded that erosion is highly dependent on the injected waste volume, as well as the slurry injection rate. To prevent these and similar problems, Okorodudu et al. [16] suggest improvement in the well and completion design, which includes the use of corrosion-resistant alloy steel, protective sleeves, hard facing of the critical parts, etc.

Although the annular waste injection method provides an opportunity to inject waste into exploratory wells and wells being drilled without interrupting the production or the drilling process (as is often the common practice in the North Sea region), in more than $80 \%$ of cases, operators selected the tubing injection method for their projects $[26,46,49]$. The main reason for this can be found in the adaptability of the tubular waste injection method, unlike annular waste injection, where the waste injection is a mandatory part of the initial well design.

\subsubsection{Tubular Injection of Drilling Waste}

If this type of injection is selected, the selected formation is covered with a steel casing and cemented. It is necessary to make a perforation in the steel pipe and set cement into the formation in order to make a pathway for future waste slurry injections (Figure 1 (2. and 3.)). According to Sipple-Srinivasan et al. [21] from Terralog Technologies Inc., the maximum length of perforated interval for a slurry fracture injection should be $10 \mathrm{~m}$ to keep the desired injection pressure and rate and with a perforation density of 20 shots per meter (phasing between $90^{\circ}$ and $120^{\circ}$ ) to get an as good as possible waste distribution in the radial direction.

\subsection{Waste Slurry Preparation and Disposal Unit}

For waste slurry preparation and injection in the selected injection well, the slurry preparation and disposal unit is used. It consists of a feed hopper; conveyance system; grinding and mixing system; water supply pump; high pressure injection pumps and storage tanks for solids, liquid waste and water (Figure 2). All elements are placed onsite within approximately $60 \mathrm{~m}$ from the wellhead of the injection well [21]. The first part of the system consists of the drilling cuttings (or waste) transportation system used for waste transportation from sources up to the slurrification unit. In the case of drilling cuttings, the simplest way for their transportation from shakers to the slurrification unit is by gravity, but there are also several other methods like auger or belt conveyors, vacuum transport systems or pneumatic bulk transports and storage systems. Selection of the appropriate waste transportation system depends on the drilling rig configuration and arrangement of equipment on it, and its efficiency depends on the quantity and composition of the waste, distance and elevation from waste sources to the slurrification unit, time interval from generation of the waste and slurry preparation and injection, etc. The slurrification unit is the second part of the slurry preparation and disposal unit, and it consists of a coarse tank (for mixing and blending of waste with water by specially designed centrifugal pumps); a classification shaker and grinder (for separation of particles based on their size and additional grinding of particles that are too large) and a fines tank (for final conditioning of the slurry by adding additional water and additives (corrosion inhibitors, biocide and friction reducers) in order to assure 
the desired slurry properties and quality control). The third part of the slurry preparation and disposal unit is an injection system consisting of a holding tank (for holding the prepared waste slurry), injection pumps and a system for data acquisition and monitoring of the injection process [49-51]. Although the slurry waste is traditionally injected by a positive displacement plunger or piston/liner-type triplex mud pumps, new laboratory research and a field trial conducted by Newman et al. [34] indicate that multistage centrifugal pumps could be advantageous in some situations.

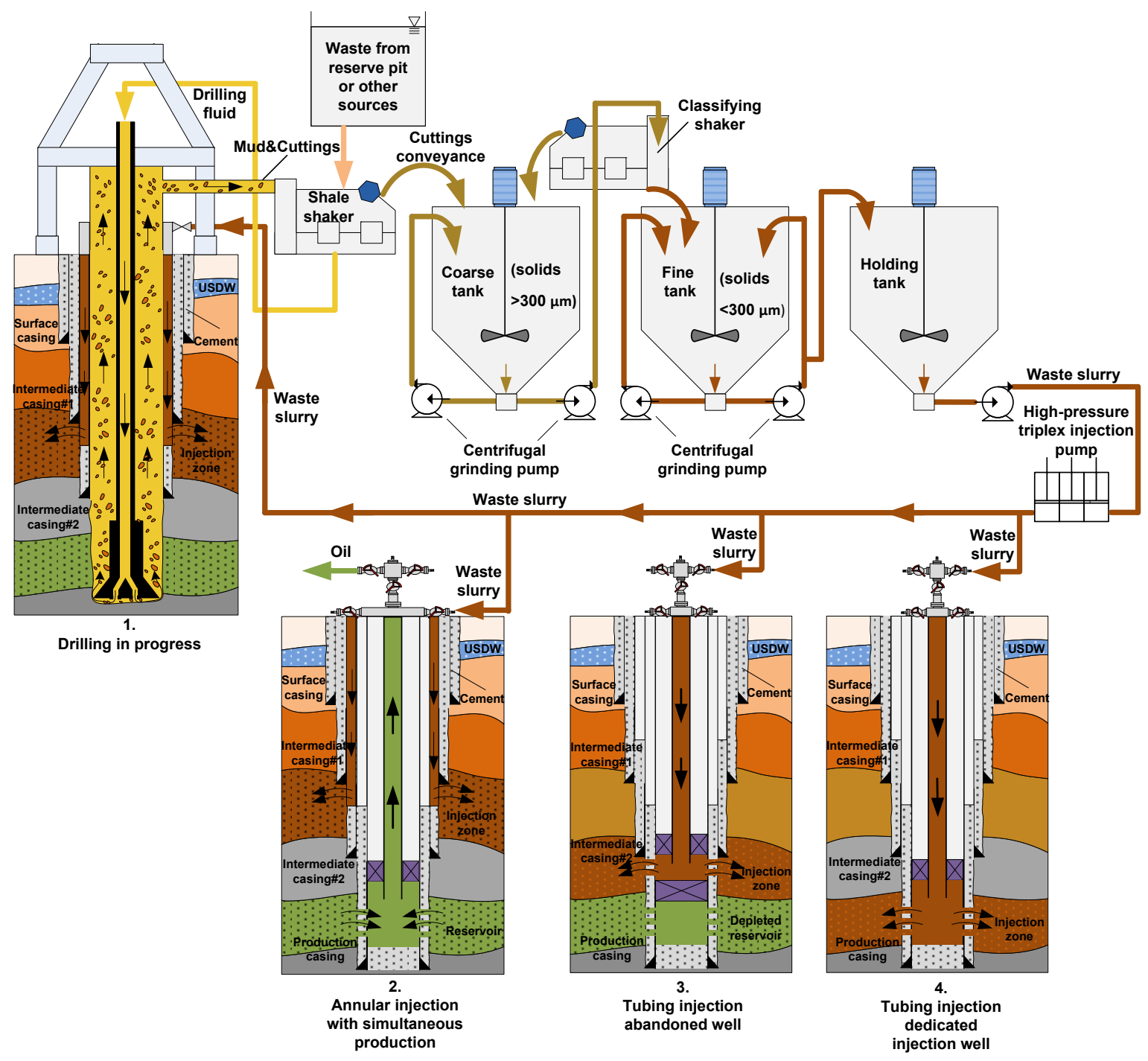

Figure 2. Waste slurry preparation and disposal unit.

In some situations, as in the case of oil and gas exploration and production waste injection in polar regions, it is necessary to heat up the waste slurry preparation water because of frozen waste material in the reservoir pits [41] or to apply winterized measures for the entire unit to assure a minimal internal temperature of $17^{\circ} \mathrm{C}[50,52]$.

In Figure 2, the waste slurry and disposal unit are shown in detail, as well as all options for adequate deep underground disposal [53].

\section{Waste Slurry}

Waste slurry is a homogeneous mixture of different kinds of waste collected during drilling and well completion activities (cuttings, used drilling fluids, contaminated rainwaters, scale, produced sands and clean up waste); water (regular or sea) and different additives [26,54]. Small amounts of 
additional waste generated at the rig site like glass, paper, pallets, plastics, rope, etc. can also be ground up, mixed with the drilling waste slurry and injected in an appropriate geological formation. Although such additional waste in the waste slurry at small concentrations does not have a detrimental effect on the entire drilling waste injection process, especially in highly porous and permeable geological strata, some problems may occur, such as a difficulty in shredding damp or wet material, clogging of the mechanical shredding unit, grinding of hard plastic to desired particles size or plugging of the injection pumps, etc. [40].

The quality of the slurry waste is one of most important parameters in the slurry waste injection, and inadequate slurry waste design frequently leads to the particle settling and sagging [38]. From this point of view, the waste slurry rheology, especially viscosity, is the most important parameter in the design of waste slurry, and the general rule is that Marsh funnel viscosity should be between 70 and $80 \mathrm{~s}$ [55]. Particle settling from the slurry suspensions is usually the result of poor slurry design, unlike sagging, which usually occurs in deviated wellbores because of Boycott's effects in static, as well as in dynamic, conditions. In both cases, the result is a significant variation of the injected slurry density through the wellbore profile, especially in the part of wellbore with inclination ranging from $45^{\circ}$ up to $60^{\circ}$. Particle settling can be accelerated by spontaneous shrinking of injected slurry and separation of the liquid phase (free water and light fluid) from the suspension through the process known as syneresis. Apart from affecting the particle settling and sagging, the waste slurry composition and, especially, rheological properties also affects fracture dimensions and propagation. This problem was noticed in the course of one of the first waste slurry injection projects (Celtic Project and the project in the Cold Lake region) in Canada, where the vertical propagation of the fraction caused by the injection of the mixture composed of waste slurry (produced sand and wastewater) and grap; the stable emulsion composed of water (from $40 \%$ up to $85 \%$ ); fine-grade silicate minerals $\left(\mathrm{clay}, \mathrm{SiO}_{2}\right.$, etc.) and asphaltene-rich fraction of the heavy oil was observed. Mixing of the grap with the waste slurry caused fracture sealing and decreasing permeability of the formation and, consequently, vertical fracture growth [37]. After the selection of appropriate waste slurry injection methods, it is necessary to select a surface system for the waste slurry preparation and injection in the selected subsurface geological formation.

Particle size and concentration also affect the above-mentioned process and need to be maintained at optimum values. The optimal particle size is between $2 \mu \mathrm{m}$ and $350 \mu \mathrm{m}$, with volume concentrations ranging from $30 \%$ up to $40 \%$ for particles less than $150 \mu \mathrm{m}$ or $20 \%$ for bigger particles [21,55]. Today, waste slurry usually contains particles whose dimensions are less than $300 \mu \mathrm{m}$ in concentration of $20-30 \%$ by waste slurry volume [51].

During the injection of waste slurry, several disposal fractures are created through high-pressure pumping [56]. After the pumping of the slurry, which comprises a certain percentage of solids in the total volume of the slurry, solids remain within the created fractures, while the liquid phase leaks into the formation. Injected solids retained within the created fracture cause formation damage by forming internal and external filter cakes, resulting in fracture propagations with every new injected batch volume. Intensity of the formation damage depends on the pore throat size distribution and solid size distribution, as well as the viscosity of the liquid phase [32].

To avoid different problems which can jeopardize the entire waste injection process, it is necessary to use one of the commercial fracture simulators to simulate the whole process and optimize different parameters (injection rate, batch volume, fracture dimensions, etc.). One of the simulator output parameters is the optional batch volume representing the sum of volumes of the fracture and the leak-off fluid and the maximum batch volume, which depends on the capacity of the drilling rig hold tank, as well as the selected injection rate and rate of cuttings slurry generation. It can be express by the following equation [55]:

$$
V_{\text {batch max }}=\frac{V_{h t} \times Q_{i n j}}{Q_{i n j}-Q_{c}}
$$


where $V_{\text {batch max }}$-maximum batch volume $\left(\mathrm{m}^{3}\right), V_{h t}$-volume of the rig holding tanks $\left(\mathrm{m}^{3}\right), Q_{i n j}$-waste slurry injection rate $\left(\mathrm{m}^{3} / \mathrm{s}\right)$ and $Q_{c}$-rate of cuttings generation $\left(\mathrm{m}^{3} / \mathrm{s}\right)$.

The selected batch volume for an intermittent process must be less than optimal, as well as the maximum batch volume, because of safety and operation limits. The duration of one batch injection can range from few hours to few days and depends on the batch volume and injection rate [32,57].

The wellhead pressure during waste injection can be estimated by the following equation [58]:

$$
p_{\text {WHIP }}=p_{\text {net }}+p_{\text {perf }}+p_{\text {clos }}+p_{a / t u b}+\Delta p_{\text {bach }}-p_{h}
$$

where $p_{\text {WHIP }}$-wellhead injection pressure $(\mathrm{Pa}), p_{\text {net }}$-net pressure $(\mathrm{Pa}), p_{\text {perf }}-$ perforation pressure drop (Pa), $p_{c l o s}$-initial fracture closure pressure $(\mathrm{Pa}), p_{a / t u b}$-friction pressure drop in casing annulus/tubing (Pa), $\Delta p_{\text {bach }}$ - pressure increase due to bach injection (Pa) and $p_{h}$-hydrostatic head (Pa).

After each batch of the injected waste slurry, it is necessary to overflush the rest of the slurry from the wellbore and the near-wellbore region to prevent solids accumulation, plugging of the injection wellbore and the deterioration of wellbore integrity. The overflushing is performed using solid-free water or seawater at offshore operations and applying the viscous pill as a spacer between the injected waste slurry and overflushing fluid. According to the research conducted by Ji et al. [36], the viscous pill volume has more a conspicuous influence on slurry displacement efficiency from wellbore then its viscosity. Gumarov et al. [33] also concluded that proper post-slurry overflushing effectively reduces in-situ stress increments after each waste slurry batch as a result of the propulsion of solids far away from the wellbore. Properties of the disposal (and cleaning) fluids depend on the properties of the disposal formation, especially if the disposal formation is shale where it is necessary to adopt disposal fluid salinity and density to prevent possible shale instability problems [55].

Table 3 summarizes the available data regarding properties of waste slurry injected in a convenient geological formation during different projects conducted worldwide in the period from late-1980s until today. Waste slurry injection parameters that were used worldwide in different injection projects in the period from late-1980s until today are shown in Table 4.

Table 3. Properties of injected waste slurry used in different injection projects.

\begin{tabular}{|c|c|c|c|c|c|}
\hline \multirow[b]{2}{*}{ Reference } & \multirow[b]{2}{*}{$\begin{array}{l}\text { Waste Slurry } \\
\text { Preparation }\end{array}$} & \multicolumn{4}{|c|}{ Properties of the Injected Waste Slurry } \\
\hline & & Type of Solid Waste & $\begin{array}{l}\text { Particle } \\
\text { Concentration } \\
\text { (by \% of } \\
\text { Volume) }\end{array}$ & $\begin{array}{c}\text { Injected } \\
\text { Volume }\left(\mathrm{m}^{3}\right)\end{array}$ & $\begin{array}{l}\text { Density } \\
\left(\mathrm{kg} / \mathrm{m}^{3}\right)\end{array}$ \\
\hline $\begin{array}{l}\text { Mahrous et al. } \\
\text { [59] }\end{array}$ & N/A & $\begin{array}{l}\text { Drilled cuttings and } \\
\text { discharged mud }\end{array}$ & $10-20$ & 95,867 & $1000-1200$ \\
\hline \multirow{3}{*}{$\begin{array}{l}\text { Mohamed et al. } \\
\text { [60] }\end{array}$} & \multirow{3}{*}{ N/A } & $\begin{array}{l}\text { Waste from oil and gas } \\
\text { production }\end{array}$ & $10-23$ & \multirow{3}{*}{$\mathrm{N} / \mathrm{A}$} & \multirow{3}{*}{$\mathrm{N} / \mathrm{A}$} \\
\hline & & Organic municipal waste & $10-12$ & & \\
\hline & & $\begin{array}{l}\text { Waste from oil and gas } \\
\text { production }\end{array}$ & $5-12$ & & \\
\hline Guo et al. [61] & N/A & N/A & up to 20 & N/A & N/A \\
\hline $\begin{array}{l}\text { Romero et al. } \\
{[62]}\end{array}$ & $\begin{array}{l}\text { Grinding of cuttings up } \\
\text { to particle diameter less } \\
\text { than } 175 \mu \mathrm{m} \text { and mixing } \\
\text { with produced water }\end{array}$ & $\begin{array}{l}\text { Drilled cuttings, discharged } \\
\text { mud and waste water }\end{array}$ & up to 20 & 33,231 & $1008-1272$ \\
\hline $\begin{array}{l}\text { Mehtar et al. } \\
\text { [63] }\end{array}$ & $\begin{array}{l}\text { Grinding of cuttings up } \\
\text { to particle diameter less } \\
\text { than } 300 \mu \mathrm{m} \text { and mixing } \\
\text { with sea water and liquid } \\
\text { waste }\end{array}$ & $\begin{array}{l}\text { Drilled cuttings, discharged } \\
\text { mud, slop and sea water }\end{array}$ & $15-20$ & 80,000 & $1200-1400$ \\
\hline Xia et al. [64] & $\begin{array}{c}\text { Using of sea water for } \\
\text { waste slurry preparation }\end{array}$ & $\begin{array}{l}\text { Drilled cuttings, water-based } \\
\text { and oil-based mud, cleaning } \\
\text { water }\end{array}$ & $10-25$ & 168,436 & $1200-1250$ \\
\hline
\end{tabular}


Table 3. Cont

\begin{tabular}{|c|c|c|c|c|c|}
\hline \multirow[b]{2}{*}{ Reference } & \multirow[b]{2}{*}{$\begin{array}{l}\text { Waste Slurry } \\
\text { Preparation }\end{array}$} & \multicolumn{4}{|c|}{ Properties of the Injected Waste Slurry } \\
\hline & & Type of Solid Waste & $\begin{array}{l}\text { Particle } \\
\text { Concentration } \\
\text { (by \% of } \\
\text { Volume) }\end{array}$ & $\begin{array}{c}\text { Injected } \\
\text { Volume }\left(\mathrm{m}^{3}\right)\end{array}$ & $\begin{array}{l}\text { Density } \\
\left(\mathrm{kg} / \mathrm{m}^{3}\right)\end{array}$ \\
\hline $\begin{array}{l}\text { Kunze et al. } \\
{[65]}\end{array}$ & $\begin{array}{l}\text { Mixture of drilled } \\
\text { cuttings and produced } \\
\text { water, removing of the } \\
\text { particles with low } \\
\text { dispersibility }\end{array}$ & $\begin{array}{l}\text { Drilled cuttings, water-based } \\
\text { mud and produced water }\end{array}$ & 21 & 5928 & 1320 \\
\hline $\begin{array}{l}\text { Fetsenets et al. } \\
\text { [50] }\end{array}$ & $\begin{array}{l}\text { Grinding of cuttings and } \\
\text { mixing with water }\end{array}$ & $\begin{array}{l}\text { Drilled cuttings, discharged } \\
\text { mud and waste water }\end{array}$ & N/A & 79,182 & N/A \\
\hline $\begin{array}{c}\text { Gumarov et al. } \\
{[33]}\end{array}$ & N/A & $\begin{array}{l}\text { Drilled cuttings and } \\
\text { discharged mud }\end{array}$ & 20 & 160,000 & N/A \\
\hline $\begin{array}{l}\text { Ovalle et al. } \\
\text { [66] }\end{array}$ & N/A & $\begin{array}{c}\text { Drilling waste from reservoir } \\
\text { pit }\end{array}$ & N/A & 11,766 & N/A \\
\hline Arfie et al. [10] & $\begin{array}{l}\text { Mixture of drilled } \\
\text { cuttings and produced } \\
\text { water }\end{array}$ & $\begin{array}{l}\text { Viscous oily fluids (oil, sand } \\
\text { and water emulsions) }\end{array}$ & $10-33$ & $1,033,000$ & N/A \\
\hline Reed et al. [67] & $\begin{array}{l}\text { Mixture of waste and } \\
\text { produced water }\end{array}$ & $\begin{array}{l}\text { Drilled cuttings, produced } \\
\text { sand, produced water, crude } \\
\text { oil (with low portion of } \\
\text { NORM) }\end{array}$ & $20-70$ & 469,002 & N/A \\
\hline $\begin{array}{l}\text { Sipple-Srinivasan } \\
\text { et al. [68] }\end{array}$ & $\begin{array}{c}\text { Grinding of } \\
\text { contaminated soil and } \\
\text { mixing with water }\end{array}$ & $\begin{array}{l}\text { Contaminated soil (with high } \\
\text { portions of clay) and } \\
\text { discharged mud }\end{array}$ & $10-35$ & 2290 & N/A \\
\hline $\begin{array}{l}\text { Sipple-Srinivasan } \\
\text { et al. [21] }\end{array}$ & $\begin{array}{l}\text { Mixing of waste with } \\
\text { produced water }\end{array}$ & $\begin{array}{l}\text { Oily residue from bottom of } \\
\text { the tanks }\end{array}$ & N/A & 45,000 & $1150-1210$ \\
\hline $\begin{array}{l}\text { Dusseault et al. } \\
\text { [37] }\end{array}$ & $\begin{array}{l}\text { Slop diluted with } \\
\text { doubled volume of the } \\
\text { produced water }\end{array}$ & Slop & $<3$ & 3911 & $1020-1080$ \\
\hline \multirow[t]{2}{*}{$\begin{array}{l}\text { Moschovidis } \\
\text { et al. [69] }\end{array}$} & \multirow{2}{*}{$\begin{array}{l}\text { Grinding of cuttings up } \\
\text { to particle diameters less } \\
\text { than } 400 \mu \mathrm{m} \text { and mixing } \\
\text { with sea water }\end{array}$} & $\begin{array}{l}\text { Fluid (usually water) used } \\
\text { for rinsing of oily cuttings }\end{array}$ & 4 & $>19,080$ & \multirow[t]{2}{*}{$\approx 1200$} \\
\hline & & $\begin{array}{l}\text { Drilled cuttings, seawater } \\
\text { and } 2 \% \text { of oil }\end{array}$ & 22 & $\approx 54,060$ & \\
\hline $\begin{array}{l}\text { Minton and } \\
\text { Secoy [48] }\end{array}$ & $\begin{array}{l}\text { Grinding of oily cuttings } \\
\text { up to particle diameters } \\
\text { less than } \\
300 \mu \mathrm{m} \text { and mixing with } \\
\text { sea water }\end{array}$ & Oily drilled cuttings & N/A & N/A & N/A \\
\hline $\begin{array}{l}\text { Willson et al. } \\
\text { [70] }\end{array}$ & $\begin{array}{l}\text { Grinding of cuttings and } \\
\text { mixing with sea water }\end{array}$ & $\begin{array}{l}\text { Oil-based mud, oily drill } \\
\text { cuttings }\end{array}$ & $\approx 15$ & 22,187 & $1170-1430$ \\
\hline $\begin{array}{l}\text { Abou-Sayed } \\
\text { et al. [71] }\end{array}$ & N/A & $\begin{array}{l}\text { Waste crude oil, acids, } \\
\text { unused proppant, discharged } \\
\text { mud, residue from bottom of } \\
\text { the tanks }\end{array}$ & N/A & 318,000 & N/A \\
\hline
\end{tabular}

Table 4. Waste slurry injection parameters used in different injection projects.

\begin{tabular}{|c|c|c|c|c|c|}
\hline Reference & $\begin{array}{l}\text { Duration of Waste } \\
\text { Injection }\end{array}$ & $\begin{array}{l}\text { Type of } \\
\text { Injection }\end{array}$ & Way of Injection & $\begin{array}{c}\text { Injection } \\
\text { Pressure (MPa) }\end{array}$ & $\begin{array}{c}\text { Flow Rate } \\
\left(\mathrm{m}^{3} \text { per Day) }\right.\end{array}$ \\
\hline $\begin{array}{l}\text { Mahrous et al. } \\
\text { [59] }\end{array}$ & 14 mounts & $\begin{array}{l}\text { Tubing } \\
\text { injection }\end{array}$ & N/A & Maximum 34.5 & N/A \\
\hline \multirow{3}{*}{$\begin{array}{l}\text { Mohamed et al. } \\
\text { [60] }\end{array}$} & $\begin{array}{c}\text { January } \\
\text { 2012-December } 2015\end{array}$ & \multirow{3}{*}{$\begin{array}{l}\text { Tubing } \\
\text { injection }\end{array}$} & $\begin{array}{l}\text { Intermittent (batch volume } 16-480 \\
\mathrm{~m}^{3} \text { ) }\end{array}$ & 6.9 & $900-1150$ \\
\hline & $\begin{array}{l}\text { December 2015-June } \\
2017\end{array}$ & & $\begin{array}{l}\text { Intermittent (batch volume 1270-1590 } \\
\mathrm{m}^{3} \text { ) }\end{array}$ & 19 & $1800-2300$ \\
\hline & $\begin{array}{l}\text { January 2012-March } \\
2018\end{array}$ & & $\begin{array}{l}\text { Intermittent (batch volume 795-1590 } \\
\qquad \mathrm{m}^{3} \text { ) }\end{array}$ & 9.5 & $2300-2750$ \\
\hline Guo et al. [61] & $\begin{array}{l}10 \text { February 2016-25 } \\
\text { January } 2017\end{array}$ & $\begin{array}{l}\text { Tubing } \\
\text { injection }\end{array}$ & $\begin{array}{l}\text { Intermittent ( } 12 \mathrm{~h} \text { of batch slurry } \\
\text { injection) with water flushing before } \\
\text { and after injection }\end{array}$ & $10.3-16.7$ & Maximum 2750 \\
\hline
\end{tabular}


Table 4. Cont.

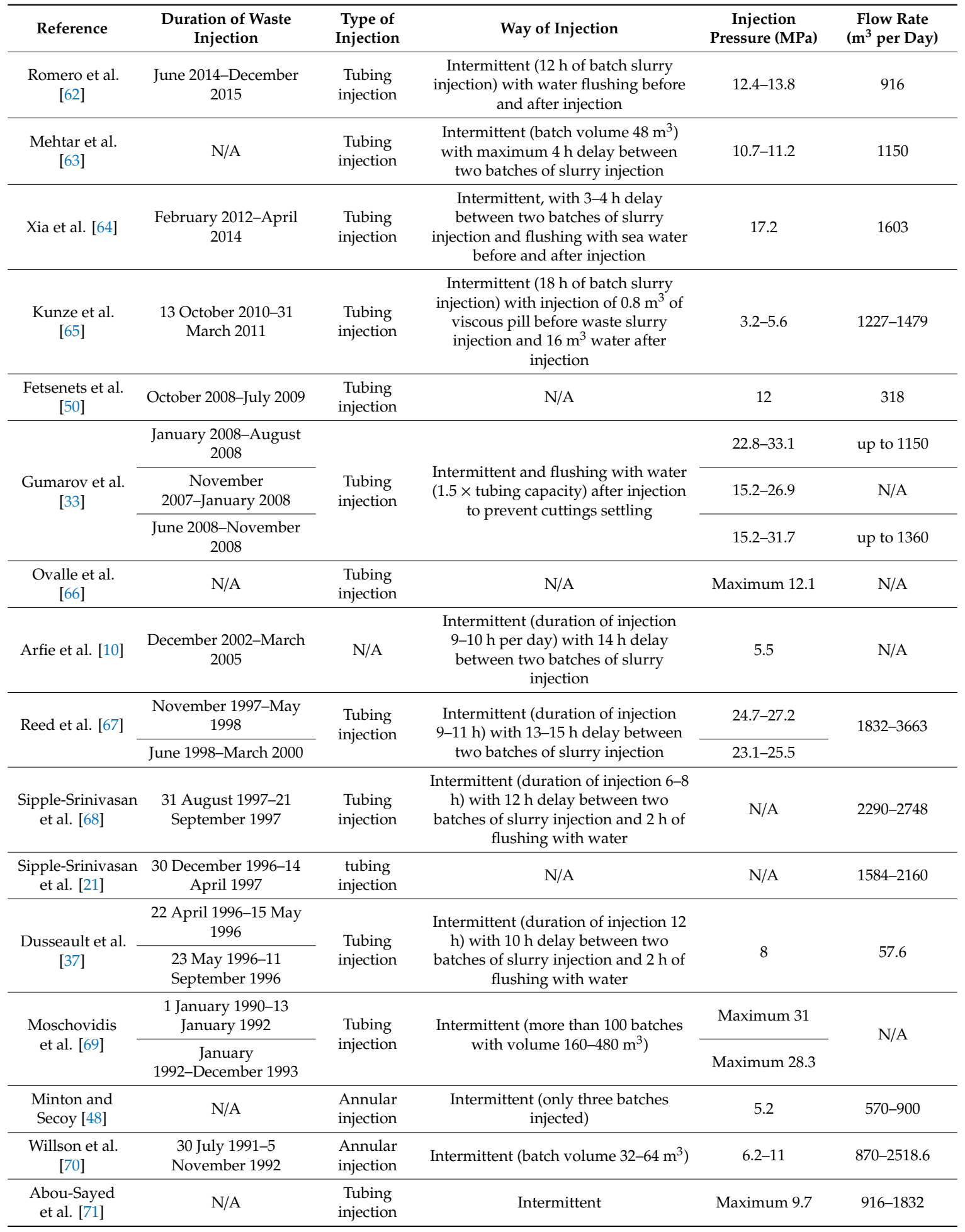

\section{Criteria for the Injection Zone Selection and Characterization}

The most important parameters for determining a suitable slurry fracture injection site are permeability, porosity, reservoir thickness, depth and structural geology characteristics of the area. Their values for successful waste injection are shown in Table 5. An equally important parameter in the selection of suitable geological formations for the waste injection above the fracture pressure is the 
fracture containment mechanism, which ensures that the created fracture will not extend beyond the injection formation borders.

Table 5. The most important parameters and their values for a successful waste injection [72,73].

\begin{tabular}{cc}
\hline Parameter & Value of Parameter \\
\hline Reservoir thickness & More than $2 \mathrm{~m}$ \\
Cap rock thickness & 4 times higher than reservoir thickness \\
Permeability & Between $10 \times 10^{-3} \mu \mathrm{m}^{2}$ and $10,000 \times 10^{-3} \mu \mathrm{m}^{2}$ \\
Reservoir depth & Between 200 and $3000 \mathrm{~m}$ \\
Structural setup & Intermediate or simple \\
Sand-shale sequence & Few layers \\
\hline
\end{tabular}

According to Guo et al. [23], there are three basic fracture containment mechanisms (barriers): stress barrier (existing of a formation above the injection zone with the higher fracture pressure), permeability barrier (existing of a high permeability formation above the injection zone with the lower fracture pressure) and modulus barrier (existing of a formation above the injection zone with the higher elastic modulus). An ideal stress barrier is the salt formation because of a higher fracture pressure gradient in comparison with the injection formation, while the ideal modulus barrier is provided by the existing limestone formation. All above-mentioned formations, such as salt, limestone or highly permeable formations, are not difficult to recognize in the lithological profile, especially in well-known areas with a large quantity of geological data.

Saif ud Din et al. [74] have taken into consideration some other parameters, putting an emphasis on the geological aspects and environmental considerations of a slurry fracture injection (Table 6). They use the same values for most parameters as those mentioned in Table 5, but some of them are somewhat different, such as reservoir thickness, which should be more than $5 \mathrm{~m}$. Additionally, porosity of the target zone should be higher than $15 \%$.

Table 6. Criteria for site suitability of an slurry fracture injection operation [74].

\begin{tabular}{cccc}
\hline & Geological Criteria & \multicolumn{2}{c}{ Environmental Criteria } \\
\hline Parameter & Value of Parameter & Parameter & Value of Parameter \\
\hline Reservoir thickness & More than $5 \mathrm{~m}$ & Economic value of formation & Low \\
Cap rock thickness & More than $10 \mathrm{~m}$ & Urban/industrial development & Far \\
Permeability & from $10 \times 10^{-3} \mu \mathrm{m}^{2}$ to $1000 \times 10^{-3} \mu \mathrm{m}^{2}$ & Impact on vegetation & Nil-minimal \\
Porosity & More than $15 \%$ & Micro-climatic impact & Reduction in temperature \\
Reservoir depth & Between 200 and $3000 \mathrm{~m}$ & Land use/landcover & Reclamation \\
Structural complexity & Undeformed or simple & Micro-elevation changes & Infinitesimal \\
Lithology & Intercalated sand-shale & Transportation & Short distance \\
Reservoir strength & Intermediate-weak & - & - \\
Groundwater source & No source nearby & - & - \\
\hline
\end{tabular}

During waste injection, an abnormally high pore pressure can occur. Therefore, it is important that the induced pressure at a short distance from the injection zone rapidly decreases to a normal level after each injection interval. Permeability is the most important factor that affects the rapid reduction of pressure, and if its value is greater than $10,000 \times 10^{-3} \mu \mathrm{m}^{2}$, the rapid leak-off (bleed-off) occurs, and such a well is not a good candidate for waste disposal [73]. Low porosity always implies a lower waste disposal capacity and more difficulty in compressing rock mass to achieve the required capacity, making it much more difficult to achieve a long-term stable waste disposal site. Waste injection into deep formations requires minimal vertical migration outside the disposal zone, whereby it is essential to have a low permeable cap rock such as a shale. This is particularly important in cases where sandstone is selected for the target zone.

The injection zone must be isolated from potable water aquifers and away from any location of economic interest, such as oil and gas fields or mines. The injection wells must be equipped with surface casing cemented to the wellhead to protect low salinity aquifers near the surface through which 
the well is drilled [11]. The distance from potable water aquifers is almost always directly related to the depth, since most aquifers are not more than $200 \mathrm{~m}$ deep [75].

There is a number of different laboratory and field techniques and tests for the characterization of the disposal domain [76] (Figure 3).

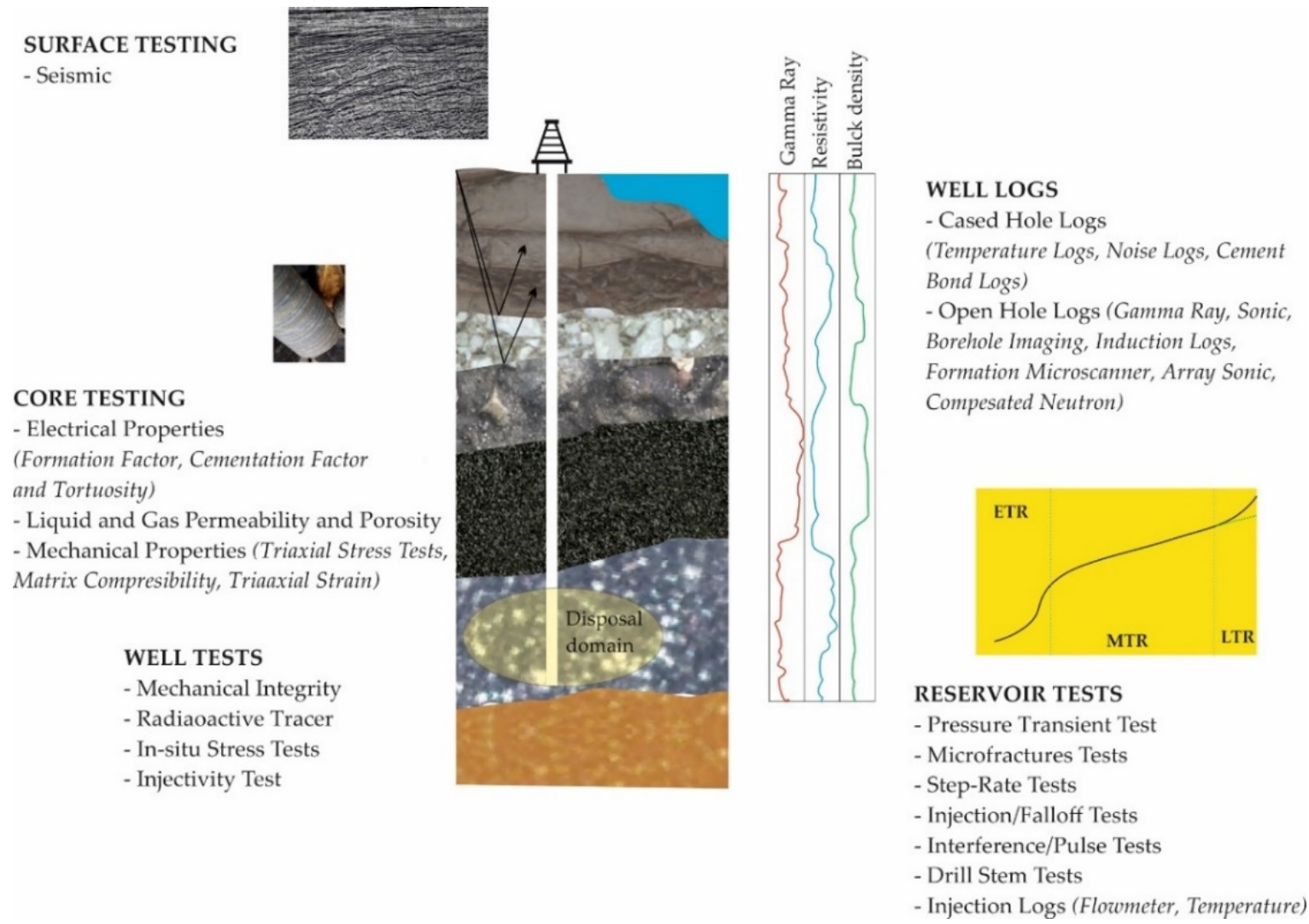

Figure 3. Disposal domain characterisations.

Table 7 summarizes the available data regarding formations selected for deep underground waste slurry injection projects worldwide in the period from the late-1980s until today. 
Table 7. Characteristics of the disposal formations.

\begin{tabular}{|c|c|c|c|c|c|c|c|c|c|}
\hline \multirow[b]{2}{*}{ Reference } & \multirow[b]{2}{*}{ Service Company } & \multirow[b]{2}{*}{ Location } & \multicolumn{7}{|c|}{ Characteristic of the Disposal Formation } \\
\hline & & & Type of Rock & Depth (m) & $\begin{array}{l}\text { Permeability } \\
\qquad\left(\mu \mathrm{m}^{2}\right)\end{array}$ & $\begin{array}{l}\text { Porosity } \\
\quad(-)\end{array}$ & $\begin{array}{c}\text { Formation } \\
\text { Fracture Pressure } \\
\text { Gradient }(\mathrm{kPa} / \mathrm{m})\end{array}$ & $\begin{array}{c}\text { Depth of } \\
\text { Perforation or } \\
\text { Annular } \\
\text { Injection (m) }\end{array}$ & Cap Rock \\
\hline $\begin{array}{l}\text { Mahrous et al. } \\
\text { [59] }\end{array}$ & Halliburton & Sakhalin, Russia & N/A & N/A & N/A & N/A & N/A & N/A & N/A \\
\hline \multirow{3}{*}{$\begin{array}{l}\text { Mohamed } \\
\text { et al. [60] }\end{array}$} & \multirow{3}{*}{$\begin{array}{l}\text { Advantek Waste } \\
\text { Management } \\
\text { Services }\end{array}$} & \multirow{3}{*}{ N/A } & \multirow{3}{*}{ Sandstone } & $1670-1710$ & $0.35-3.5$ & 0.25 & 10.1 & \multirow{3}{*}{ N/A } & \multirow{3}{*}{ N/A } \\
\hline & & & & $1380-1460$ & $0.3-0.5$ & 0.26 & 10.1 & & \\
\hline & & & & 1900-1950 & $0.05-0.1$ & 0.17 & 9.1 & & \\
\hline Guo et al. [61] & $\begin{array}{l}\text { Advantek Waste } \\
\text { Management } \\
\text { Services }\end{array}$ & Texas, USA & $\begin{array}{l}\text { Sandstone } \\
\text { interbedded } \\
\text { with shale }\end{array}$ & 1950-2030 & $0.0001-0.105$ & $0.185-0.259$ & $17.2-18.1$ & N/A & Tick shale layer \\
\hline $\begin{array}{l}\text { Romero et al. } \\
\text { [62] }\end{array}$ & $\begin{array}{c}\text { Halliburton/ } \\
\text { Petroamazonas }\end{array}$ & $\begin{array}{l}\text { Apaika-Nenke } \\
\text { Field, Ekvador }\end{array}$ & N/A & N/A & N/A & N/A & 12.9 & N/A & N/A \\
\hline $\begin{array}{l}\text { Mehtar et al. } \\
\text { [63] }\end{array}$ & M-I Swaco & Abu Dhabi, UAE & Limestone & $1315-1390$ & N/A & N/A & $17.7-19$ & N/A & Dolomite and limestone \\
\hline Xia et al. [64] & $\begin{array}{c}\text { Terralog } \\
\text { Technologies Inc., } \\
\text { Saudi Aramco }\end{array}$ & $\begin{array}{l}\text { Manifa, Saudi } \\
\text { Arabia }\end{array}$ & Sandstone & $\begin{array}{l}\text { 1827-1994 } \\
\text { (MD) }\end{array}$ & 2.24 & 0.24 & N/A & 1981-1990 & Shale and sandstone alteration \\
\hline $\begin{array}{c}\text { Kunze et al. } \\
\text { [65] }\end{array}$ & ExxonMobil & Colorado, USA & Sandstone & $\begin{array}{l}\text { 1684-1752 } \\
\text { (MD) }\end{array}$ & N/A & N/A & N/A & $1710-1725$ & N/A \\
\hline $\begin{array}{c}\text { Fetsenets et al. } \\
\text { [50] }\end{array}$ & $\begin{array}{c}\text { Gazpromneft- } \\
\text { Khantos/M-I Swaco }\end{array}$ & $\begin{array}{l}\text { Western Sibir, } \\
\text { Russia }\end{array}$ & N/A & $\begin{array}{l}\approx 1300 \text { and } \\
1700\end{array}$ & N/A & N/A & N/A & N/A & N/A \\
\hline $\begin{array}{c}\text { Gumarov et al. } \\
\text { [33] }\end{array}$ & M-I Swaco & Caspian Sea & Mudstone & N/A & N/A & N/A & N/A & N/A & N/A \\
\hline $\begin{array}{l}\text { Ovalle et al. } \\
\text { [66] }\end{array}$ & M-I Swaco & South America & Sandstone & 1401 & N/A & N/A & N/A & $1401-1408$ & Limestone \\
\hline \multirow{2}{*}{$\begin{array}{l}\text { Arfie et al. } \\
\text { [10] }\end{array}$} & \multirow{2}{*}{$\begin{array}{c}\text { Terralog } \\
\text { Technologies Inc. }\end{array}$} & \multirow{2}{*}{ Duri, Indonesia } & \multirow{2}{*}{$\begin{array}{l}\text { Unconsolidated } \\
\text { sandstone }\end{array}$} & 383 & \multirow{2}{*}{ N/A } & \multirow{2}{*}{ N/A } & \multirow{2}{*}{ N/A } & $380-389$ & \multirow{2}{*}{ Shale } \\
\hline & & & & 418 & & & & 419-430 & \\
\hline
\end{tabular}


Table 7. Cont.

\begin{tabular}{|c|c|c|c|c|c|c|c|c|c|}
\hline \multirow[b]{2}{*}{ Reference } & \multirow[b]{2}{*}{ Service Company } & \multirow[b]{2}{*}{ Location } & \multicolumn{7}{|c|}{ Characteristic of the Disposal Formation } \\
\hline & & & Type of Rock & Depth (m) & $\begin{array}{l}\text { Permeability } \\
\qquad\left(\mu \mathrm{m}^{2}\right)\end{array}$ & $\begin{array}{l}\text { Porosity } \\
(-)\end{array}$ & $\begin{array}{c}\text { Formation } \\
\text { Fracture Pressure } \\
\text { Gradient }(\mathrm{kPa} / \mathrm{m})\end{array}$ & $\begin{array}{c}\text { Depth of } \\
\text { Perforation or } \\
\text { Annular } \\
\text { Injection (m) }\end{array}$ & Cap Rock \\
\hline \multirow{2}{*}{$\begin{array}{l}\text { Reed et al. } \\
\text { [67] }\end{array}$} & \multirow{2}{*}{ Chevron } & \multirow{2}{*}{ Louisiana, USA } & \multirow{2}{*}{ Sandstone } & \multirow{2}{*}{$1341-1524$} & \multirow{2}{*}{$0.5-2.0$} & \multirow{2}{*}{0.23} & $16.5-18.1$ & $1512-1524$ & \multirow{2}{*}{$\begin{array}{l}\text { Shale and sand alteration } \\
\text { (thickness of the layers } \\
3-45 \mathrm{~m} \text { ) }\end{array}$} \\
\hline & & & & & & & $17.4-19.5$ & $1378-1390$ & \\
\hline $\begin{array}{l}\text { Sipple-Srinivasan } \\
\text { et al. [68] }\end{array}$ & $\begin{array}{c}\text { Terralog } \\
\text { Technologies Inc. }\end{array}$ & $\begin{array}{l}\text { West Coyote, } \\
\text { California }\end{array}$ & $\begin{array}{l}\text { Depleted oil } \\
\text { reservoir }\end{array}$ & 1250 & 0.5 & 0.3 & 5.2 & $1237-1264$ & Shale $(969-1189 \mathrm{~m})$ \\
\hline $\begin{array}{l}\text { Sipple-Srinivasan } \\
\text { et al. [21] }\end{array}$ & $\begin{array}{c}\text { Terralog } \\
\text { Technologies Inc. }\end{array}$ & $\begin{array}{l}\text { Saskatchewan, } \\
\text { Canada }\end{array}$ & N/A & N/A & N/A & N/A & N/A & N/A & N/A \\
\hline $\begin{array}{l}\text { Dusseault } \\
\text { et al. [37] }\end{array}$ & $\begin{array}{c}\text { Terralog } \\
\text { Technologies Inc. }\end{array}$ & Alberta, Canada & Sandstone & $732-752$ & 0.5 & 0.27 & $17.5-19.5$ & $745.5-748.5$ & $\begin{array}{l}\text { Low permeability shale } \\
(454-717 \mathrm{~m})\end{array}$ \\
\hline \multirow{2}{*}{$\begin{array}{l}\text { Moschovidis } \\
\text { et al. [69] }\end{array}$} & \multirow{2}{*}{ Amoco } & \multirow{2}{*}{$\begin{array}{l}\text { Valhall, } \\
\text { The North Sea }\end{array}$} & \multirow{2}{*}{ Siltite (shale) } & 2395 & \multirow{2}{*}{ N/A } & \multirow{2}{*}{ N/A } & \multirow{2}{*}{$\approx 13.6$} & \multirow{2}{*}{ N/A } & \multirow{2}{*}{ Shale } \\
\hline & & & & 2467 & & & & & \\
\hline $\begin{array}{l}\text { Minton and } \\
\text { Secoy [48] }\end{array}$ & $\begin{array}{l}\text { BP Exploration } \\
\text { Operating Co. }\end{array}$ & $\begin{array}{l}\text { Offshore platform } \\
\text { Clyde, The North } \\
\text { Sea }\end{array}$ & Shale & $760-1720$ & N/A & N/A & N/A & 760 & N/A \\
\hline $\begin{array}{l}\text { Willson et al. } \\
\text { [70] }\end{array}$ & BP Norway & $\begin{array}{l}\text { Offshore platform } \\
\text { Gyda, The North } \\
\text { Sea }\end{array}$ & $\begin{array}{l}\text { Mudstone } \\
\text { (shale) }\end{array}$ & 900 & N/A & N/A & 10.2 & 900 & $\begin{array}{l}\text { Sandstone interbedded with } \\
\text { shale }(250-400 \mathrm{~m})\end{array}$ \\
\hline $\begin{array}{l}\text { Abou-Sayed } \\
\text { et al. [71] }\end{array}$ & $\begin{array}{l}\text { ARCO Oil \& Gas } \\
\text { Inc. }\end{array}$ & $\begin{array}{l}\text { Prudhoe Bay, } \\
\text { Alaska }\end{array}$ & $\begin{array}{l}\text { Sandstone and } \\
\text { gravel }\end{array}$ & $\approx 650$ & $1-2$ & N/A & $18.5-19.2$ & N/A & $\begin{array}{c}30 \mathrm{~m} \text { of shale and permafrost } \\
\text { up to surface }\end{array}$ \\
\hline
\end{tabular}




\section{Disposal Domain Characterization during the Planning and Executing Phase of Underground Waste Disposal}

The main task of engineers is the characterization and visualization of the waste disposal domain, especially during waste injection above the fracture pressure of the disposal formation and prediction with some certainty of the fracture geometry (height and length). Disposal of the waste from drilling activities through a slurry injection into a suitable geological formation is very similar to the hydraulic fracturing as a method for reservoir stimulation, as well as to the lost circulation as a common problem during well drilling [57]. Due to that, for the purpose of numerical simulations and modeling of downhole waste slurry injection, commercial hydraulic fracture stimulators were used [25]. Similarity and differences between these two downhole injection methods in the oil and gas industry are presented in Table 8. As in the case of a reservoir stimulation through hydraulic fracturing, the quality of the created model and simulation strongly depends on accessibility and reliability of geological and operational information, as well as its improvement with additional information during the implementation of the project [26,77]. The required input information about the geological formation which is being considered for waste slurry injection can be obtained from wireline logs, well testing or through special petrophysical laboratory methods applied to core samples with reference to their reliability [39]. Guo et al. [16] suggest the probabilistic approach for the assessment of the risk and containment of injected waste slurry, while Okorodudu et al. [57] propose using a three-dimensional hydraulic simulator because of its capability to predict fracture geometry with more confidence through a simulation of single/multiple fractures, visualization capability, ability to achieve a more accurate result using less assumptions and assess risks based on a probabilistic model.

Table 8. Comparison between reservoir stimulations by fracturing and underground drilling waste injection above the formation fracture pressure $[2,35]$.

\begin{tabular}{ccc}
\hline Per Well Site & $\begin{array}{c}\text { Stimulation } \\
\text { (Hydraulic Fracturing) }\end{array}$ & $\begin{array}{c}\text { Waste Injection } \\
\text { (Above Formation Fracturing Pressure) }\end{array}$ \\
\hline Batch volume $\left(\mathrm{m}^{3}\right)$ & $160-800$ & $8000-800,000$ \\
Injection rate $\left(\mathrm{m}^{3} / \mathrm{s}\right)$ & $0.0265-0.265$ & $0.00265-0.053$ \\
Treatment time & Hours & Weeks, months or years \\
Fluid type & Crosslinked guar & Bentonite mud, xanthan gum \\
Viscosity $(\mathrm{P} \cdot \mathrm{s})$ & 0.2 & $0.002-0.08$ \\
Solid type and size $(\mathrm{m})$ & Proppant $\left(1680 \times 10^{-6} / 1000 \times 10^{-6}-841 \times 10^{-6} / 420 \times 10^{-6}\right)$ & Cutting $\left(\right.$ less than $\left.300 \times 10^{-6} \mathrm{~m}\right)$ \\
Concentration $(\mathrm{vol} \%)$ & or $(12 / 18-20 / 40$ mesh) & or (less than 40 mesh proppant) \\
\end{tabular}

The information provided in Table 8 is average and based on field experience. There are many examples that exceed these numerical values by several orders of magnitudes. For examples, one of the largest underground drilling waste injection projects was realized in Alaska by the end of 2002, with more than 2.5 million cubic meters of slurry waste injected per well [19].

Fracture propagation is governed by the mechanical properties of the injection zone and surrounding formations. During slurry injection, surface injection pressure must be carefully observed, considering that undesirable or rapid injection pressure build-up could jeopardize the operational life of an injection well and limit its waste disposal capacity [33]. Usually, the waste disposal domain in a slurry fracture injection is idealized with a "wagon-wheel" uniform multi-fracture domain (Figure 4a), with multiple fractures of uniform width or uniform strain [56]. Despite this assumption, Ji et al. [51] and Shokanov et al. [78] found that a "wagon-wheel" multi-fracture disposal domain is not a general case in slurry injection, and in some cases, it is more likely to reopen the existing fracture and increase it or make a branch from it than to create a new fracture with a different azimuth (Figure $4 b, c)$. Willson et al. in 1999 [25] conducted a comprehensive laboratory research related to the fracture formation in different types of rocks and observed a formation of multiple fractures in the majority of examined rock (formation) samples as a result of an intermittent injection process. The appearance of formation damage during the batch slurry waste injection and consequent change of the formation leak-off properties can directly affect the fracturing process and propagation of the disposal domain. If a 
new fracture or branch is created with each newly injected batch volume, the leak-off properties and the formation damage will depend on the proportion of the formation damage from previous injections [57]. Based on a large number of data from eight projects in the USA and Canada and the published information, Bruno et al. concluded that, in large-scale injection projects, multiple fractures are likely to occur as a result of reduction in the fracture conductivity in combination with a stress increase within the waste pod. Additionally, with every newly injected volume during the intermittent injection process, a new fracture will be created with a variation in azimuth between $30^{\circ}$ and $60^{\circ}$ compared to the previous one [22].

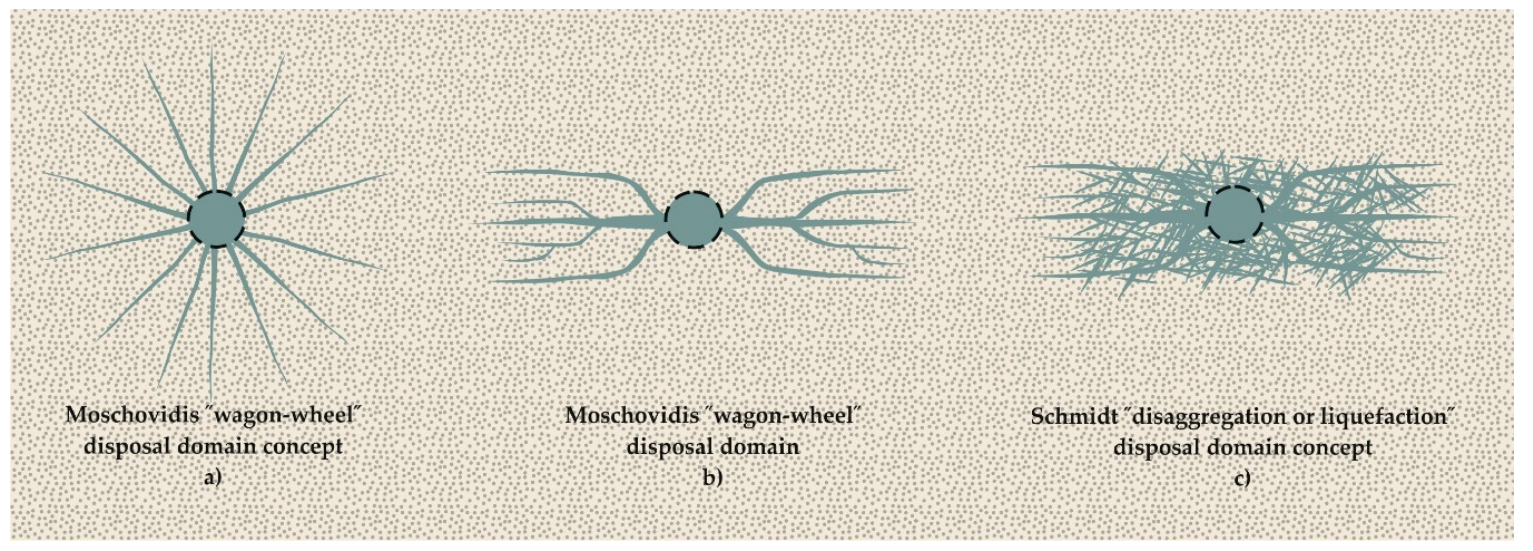

Figure 4. Different models for the characterization of a disposal domain.

There is also a possibility of the creation of a horizontal fracture during a fracture waste injection if overburden stress is or becomes less stressed because of horizontal maximum and minimum stress alterations in the disposal zone. In this situation, regardless of the principle stress state around the cased cemented hole, the first fracture is vertical, and after that, it changes direction in the horizontal plain (" $\mathrm{T}$ " shape fracture). If a previous simulation indicates the possibility for the creation of a horizontal fracture at any moment, special attention should be paid to the possibility of fracture propagation up to the surface or the seabed through branching because of the decrease of overburden stress $[2,79]$.

No matter which of the above theories is correct, waste slurry injection inevitably leads to changes in local in-situ stress, regardless of the formation that has been selected for injection. Injected waste changes the local stress through three basic mechanisms [27,32,33]:

- increasing the local in-situ stress as a result of filling the formation with injected material.

- thermal alteration of the local stress as a result of temperature dilatation during and after waste injection. These alterations are consequences of cold slurry injection within subsurface formations with certain constant temperatures.

- In-situ local stress changes as the result of a pore pressure increase and poro-elastic effect.

Except the local in-situ stress and their changes during slurry injection, the creation of a new fracture strongly depends on the stress anisotropy, especially in deviated wells.

Slurry fracture injection at pressures above the formation fracture pressure is usually used for the disposal of large quantities of waste generated during the drilling and completion phase into sandstones of relatively high porosity. On the other hand, the injection of the same slurry waste in soft formations is still relatively unexplored and usually results in various downhole problems, such as a casing collapse because of excessive movement of the soft formation and permanent pressurization and filling of the injection zone or spreading of the injected waste slurry out of target formation [22]. Although soft formations have large storage capacities, fracture modeling is always challenging, because the relationships between pressure and fracture widths are different in comparison with hard formations. Abou-Sayed et al. [32] found that fractures with branches and channels are occurring 
during slurry waste injections into the soft formation above the fracture pressure. Waste from oil and gas exploration and production activities can also be injected into salt caverns as waste slurry injection below the formation fracture pressure. This concept has been continuously developed and researched since 1990 but with limited applications in the North American region, mostly because of state regulations and rules.

Slurry waste can be injected in vertical, deviated and horizontal wells. Although the approach to slurry injection and the process itself are similar, Zaki et al. [58] found that the disposal domain formed by a batch injection of slurry waste through a horizontal well is different from the disposal domain formed during injection of the same waste trough a vertical or slightly deviated wellbore. This is the result of the wellbore position in regards to the injection zone and dynamic field stress distribution along the horizontal part of the wellbore.

\section{Injection Well Integrity}

During drilling waste injection, it is necessary to ensure both the internal and the external mechanical integrity of the injection wells. According to regulations provided by the US Environmental Protection Agency, the injection well is considered to possess mechanical integrity if there is no significant leakage in the pipes installed inside the wellbore (tubing or casing) or on the packer and if there is no significant injected fluid movement behind the wellbore to the underground sources of drinking water [80]. Well integrity of the offset well within the radius of $600 \mathrm{~m}$ from the injection well site is also important to prevent possible unwanted movements of the injected waste outside the injection formation and the contamination of underground sources of drinking water. According to the research conducted by Bruno et al. [22], almost all contamination during the waste slurry injection process is the result of communication through an adjacent offset well because of a poor primary cementation. Some authors provide special recommendations for injection well drilling and completion design to meet the requirements of the slurry injection process itself and to ensure mechanical and hydraulic integrity. For example, during the planning phase for an oily waste slurry injection at the Duri Oil Field, engineers have special technical requirements for injection well drilling and completion design, considering specific characteristic of the selected geological formation (larger diameter of a drilled hole with regards to selected casing to ensure a thicker cement sheath, drilling rate of a hole whose minimum length is $75 \mathrm{~m}$ to accept any formation sand intake and deep perforation to ensure better communication between the injection well and selected formation) [10]. In some areas like the North Slope of Alaska with a permanently frozen ground and without sources of drinking water, there is no possibility of ground water contamination $[9,31,47]$.

The injected waste can leak out of the disposal zone through an inappropriately plugged wellbore, microchannels beyond the casing, fracture that intersects another wellbore, faulted zone or overcome the disposal zone sealing layer (cap rock), etc. (Figure 5). 

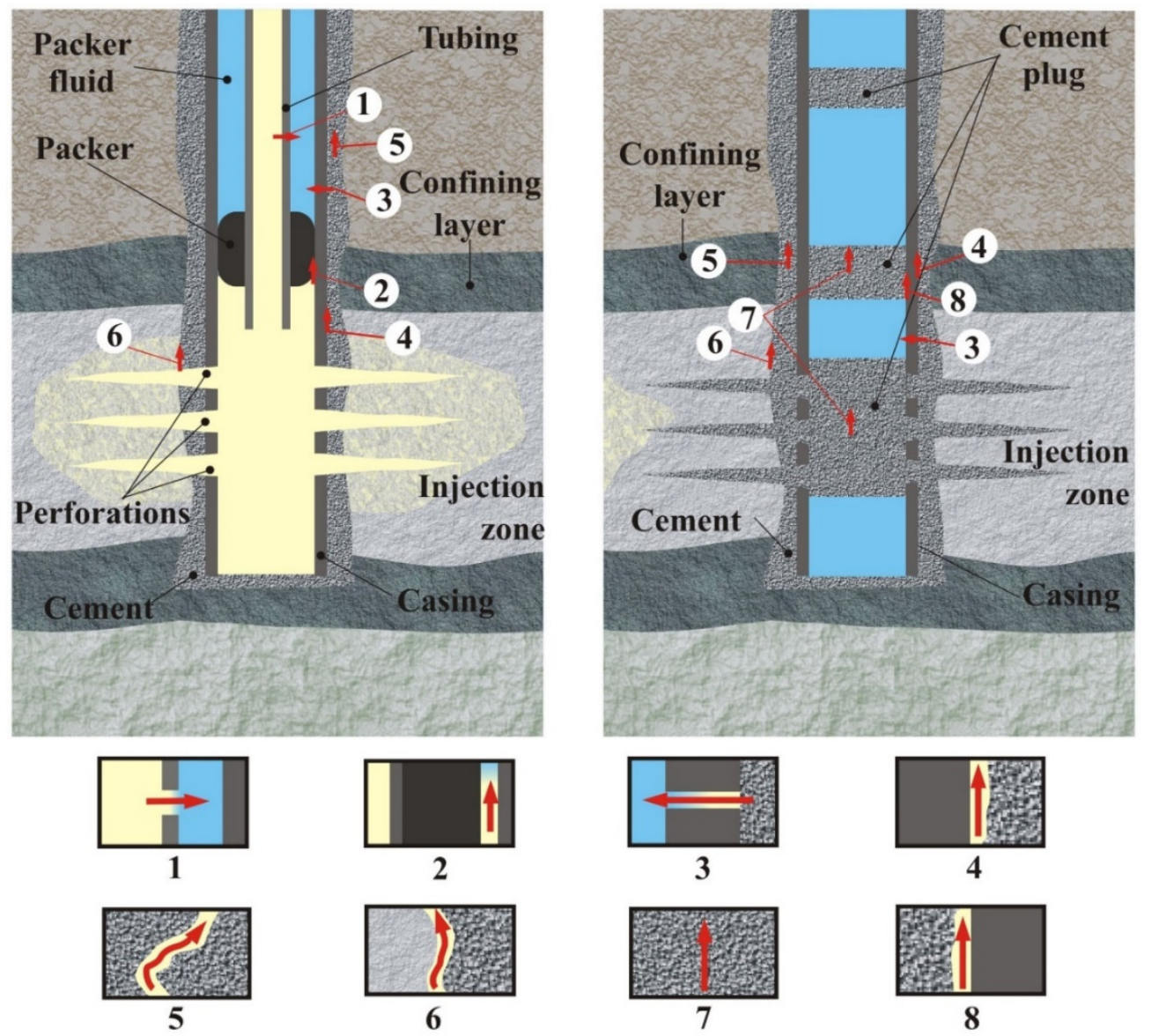

Figure 5. Possible injected waste migration pathways [81].

\section{Injection Process Monitoring}

One of the most important engineering tasks in downhole waste slurry injection is to provide a permanent retention of injected waste within the disposal domain and prevent any unwanted movement of waste back to the surface or up to subsurface sources of drinking water.

Although deep subsurface waste injection is proven to be an environmental acceptable disposal option for waste from oil and gas exploration and production activities, the possibility of severe impacts on the environment still exist. This possibility stems from inappropriate process designs, lack of data and inadequate engineering practices, as well as poor project implementation and lack of systematic surveillance. The existence of natural faults in the vicinity of injection wells can represent possible pathways for injected waste migration upward towards the top of the fault or to the surface if the injection process and created fractures caused its reactivation. Shen et al. [82] suggest using numerical and analytical/semi-analytical methods for simulation of the reactivation process for a specific fault, where the first one is more useful because of its simplicity. Based on their simulations and the developed of a numerical geomechanical model, it was possible to predict fault reactivation in the vicinity of an injector well during deep waste injection offshore of West Africa. They strongly suggest direct or indirect pore pressure monitoring at the fracture/fault intersection point during the injection process to minimize the risk of fault reactivation. According to Lele et al. [83] and Liu et al. [84], hydraulic fracturing, which is a reservoir stimulation method, causes microseismic events with magnitudes from 2 to 3, though microseismic events with the magnitudes higher than 2.5 are really rare. It is to be expected that similar microseismic events would occur also during deep underground waste injection above the formation fracture pressure, but it does not mean that a consequence of this action is the appearance of an earthquake [85]. Injection of wastewater from a reservoir stimulation and hydrocarbon production from an unconventional reservoir also results in seismic activity [86]. The 
aforementioned microseismic events, caused by the injection process itself or naturally occurring events, can result in unwanted movement of disposed waste upwards towards the surface. Since the injected waste from drilling activities may contain certain amounts of oily cuttings, oil-based muds, lubricants, heavy metal ions, etc., its movement up towards the surface can have tremendous unwanted effects on underground sources of drinking water and the environment in general [87].

Monitoring of the slurry waste injection process can be accomplished through active single-well monitoring of the injection process (injection rate and pressure, injected volume and slurry rheology); downhole monitoring (radioactive tracers, bottomhole tilt meters, temperature survey and electromagnetic measurements); testing formation response (measurement of bottom hole pressure) and remote unconventional monitoring by microseismic or surface deformation (surface tilt meters) or from adjacent wells (multiple well methods) [21,39,41]. Except surface and bottomhole pressure monitoring, all other methods provide limited data or are applicable in certain periods of time, and some of them, like microseismic and tilt meters, are too expensive and limited to large-scale projects [39]. Microseismic is a pretty accurate method for defining the main fracture and its propagation but with a limited possibility of the differentiation in downhole seismic events from different sources (for example, propagation of the same fracture or creation of branches and fissures). This problem can be eliminated by adding different materials which create noise (detonation) in the main fracture during the injection or shut-in period [26]. Utilization of different radioactive tracers in waste slurry and an appropriate logging program may be very useful in the determination of the disposal domain, especially in the determination of injection points and their changes during the lifetime of the project [40].

Pressure changes during the injection of one batch's volume is presented in Figure 6. Despite the flow being constant, the injection pressure may vary for a given value during the slurry waste injection because of the fracture's growth change, change in local in-situ stress and disposal of solids within the formation. Fracture growth and thermal changes during the injection of cooler waste slurry will cause the decrease of injection pressure, while pore pressure increases, and solid storage within the formation has a completely opposite effect on injection pressure.

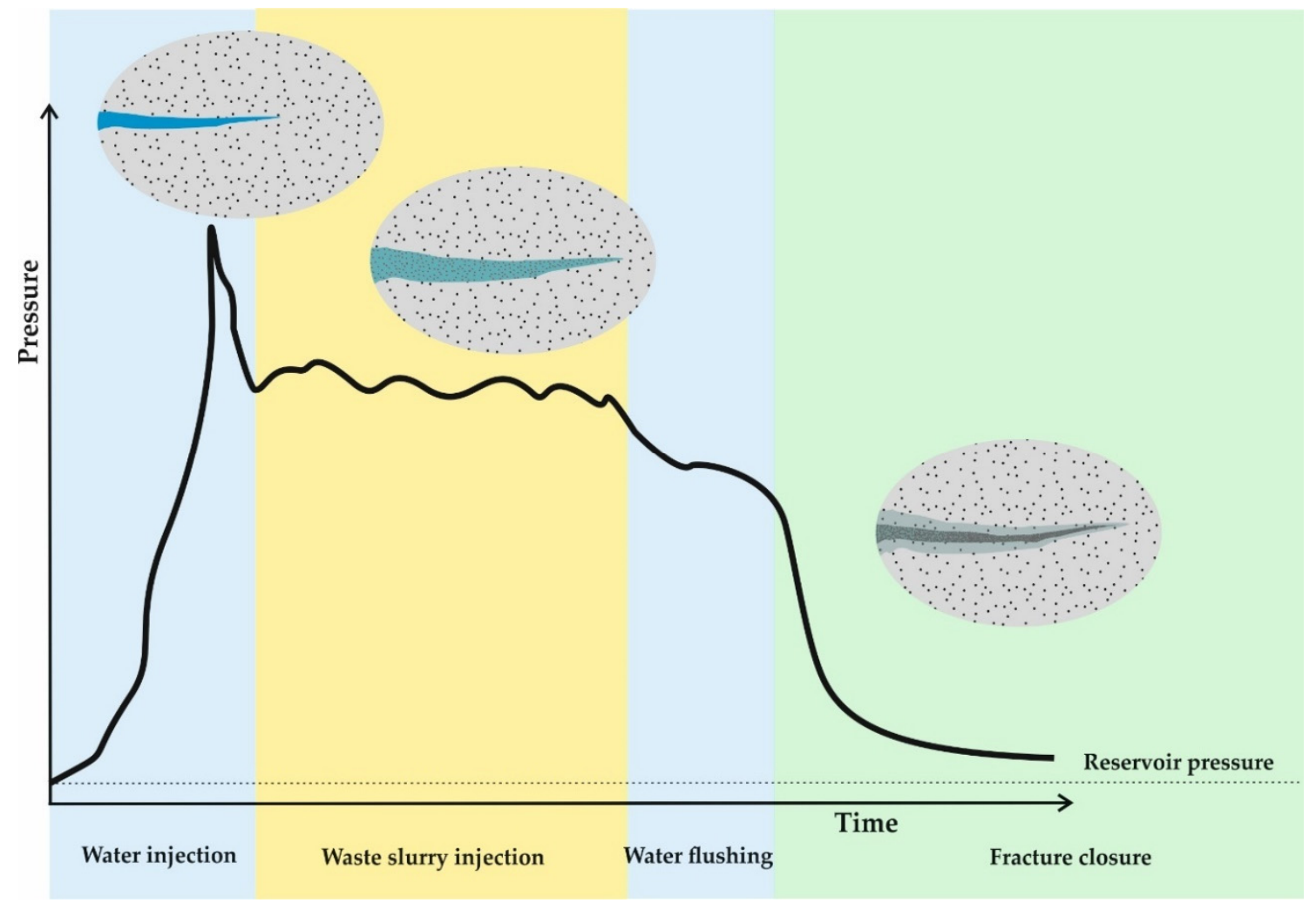

Figure 6. Pressure development during the waste slurry injection. 


\section{Abandonment and Plugging of Injection Wells}

The final task in the injection of waste from drilling activities is proper plugging and abandonment of the injection well, including well preparation and plugging. Injection well preparation phase includes cleaning of the well and establishing static equilibrium with proper density of the mud weight to prevent inflow of different fluids or gases into the wellbore. The inflow of fluids or gases into the wellbore during the well-plugging process and setting of the cement plug may have detrimental impacts on the quality of the cement plug, as well as the quality of the entire injection well-plugging process.

The injection well-plugging process can be done in two ways: filling the whole borehole with cement slurry or setting cement plugs at different, previously determined depths by applying some of the cement plugs setting techniques, known in the petroleum industry as the balance method, cement retainer method or two-plug method. According to the survey that was conducted early in the 1980s in the United States of America and ordered by the U.S. Environmental Protection Agency, only 15\% of abandoned wells were cemented from the top down to the bottom [88].

Although immediate well plugging and abandonment activities are recommended when project requirements and tasks have been fulfilled, prolongation of this process can be useful for many reasons. Some alternatives to immediate well plugging and abandonment may be setting the time period for renewing operations or abandonment, mechanical integrity test, self-reporting and monitoring water levels or aquifers. Their advantages and disadvantages are presented in Table 9.

Table 9. Different alternatives to immediate plugging and abandonment of an injection well [88].

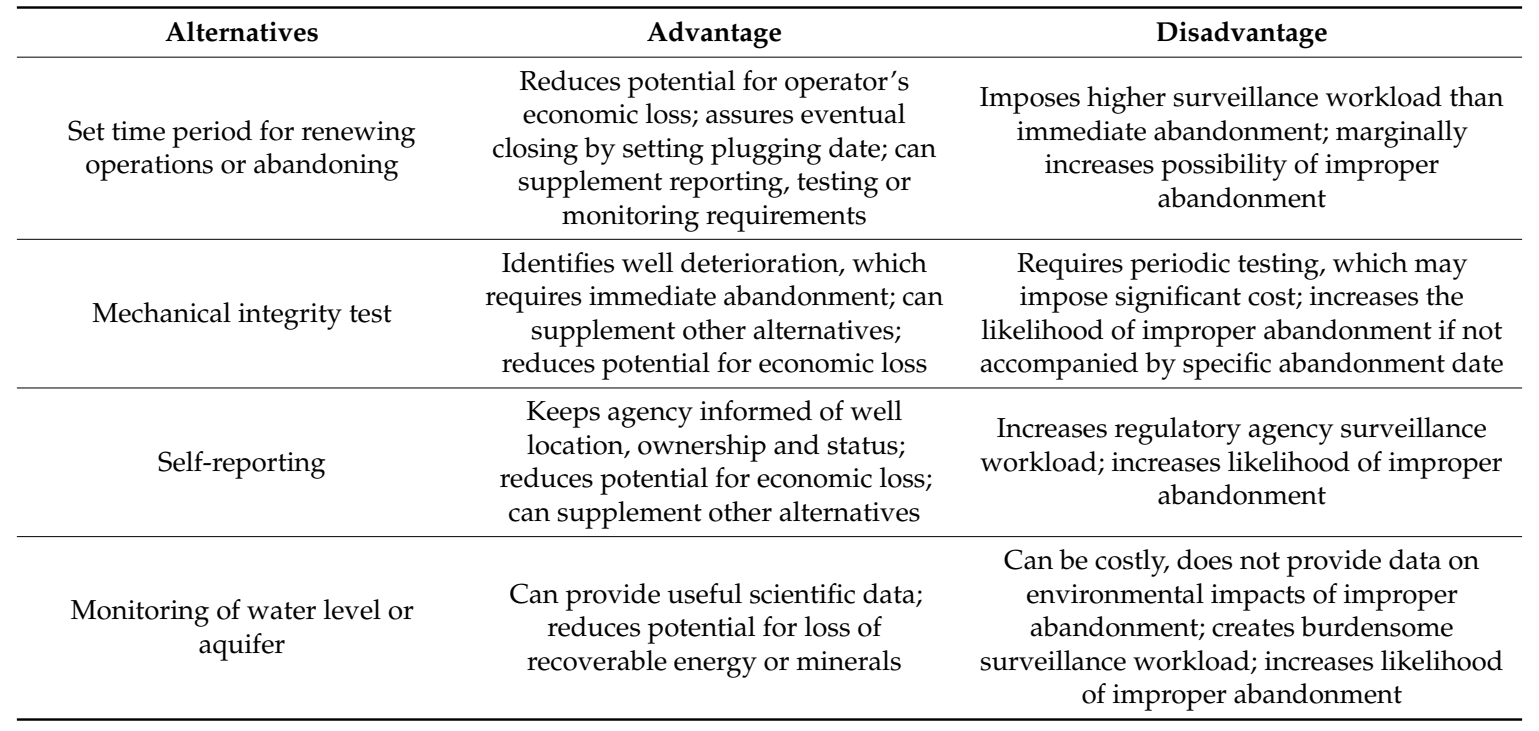

\section{Discussion and Conclusions Remarks}

Petroleum industry through oil and gas exploration and production activities generates large amounts of different wastes which must be disposed of in a safe manner, with minimum environmental impacts and without any influence on human health. Most of this waste is made up from drilled cuttings, discharged muds and produced water, and its quantities depend on activities in a certain year. Over the decades, produced reservoir water has been constantly and permanently disposed of through underground injection in the same reservoir where it came from, with the positive impact of keeping the reservoir pressure. Waste, generated through well-drilling and completion activities, can be permanently disposed of using different available techniques whose selection primarily depends on state or country regulations and legislature and the availability of certain waste disposal methods in an area, as well as waste kinds and quantities.

With the new regulations and growing concerns for the environment, operators make additional efforts to meet the new standards and requirements. This is especially important in the case of the 
development of new oil and gas fields in environmentally sensitive areas, onshore and offshore. In that regard, the operators try to minimize generated waste volume through recycling and reusing and selecting the best available methods for permanent waste disposal.

Since the 1990s, when it became widely used, deep downhole injections of waste generated by drilling activities, as well as other wastes from oil and gas exploration and production activities, positioned itself as the leading technology for permanent waste disposal. Despite large numbers of different ongoing and past deep underground waste slurry injection projects, there is limited and incomplete information about them. As can be seen from Tables 4, 5 and 7, information is mostly available through conference papers and provided by service companies that ensure technology and technical support for the project on an operator's site. Although the data collected is limited and incomplete, some general statements can be made, because it covers the period from the beginning up until today. Based on the data presented in Figure 7, it can be concluded that the majority of waste is injected in sandstone formations ( $67 \%$ of all analyzed projects), followed by mudstone and shale formations (13\% each) and, finally, in limestone formations (7\%) (Figure 6). Despite the fact that sandstone represents the best choice for deep underground waste disposal by injection, selection of an appropriate formation is more complex. The data obtained are in direct correlation with recommendations and general information provided in this paper.

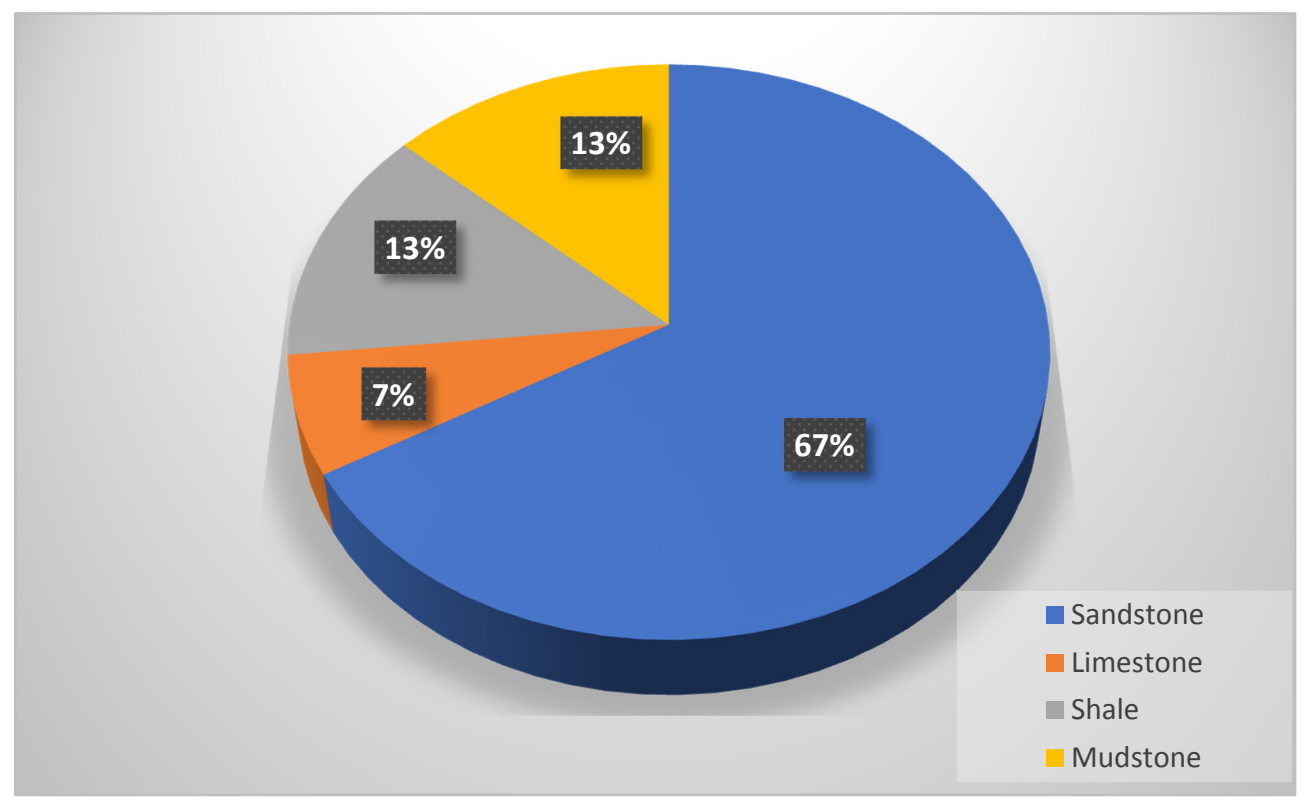

Figure 7. Formations selected for deep underground disposal of waste from drilling activities (based on data from Table 7).

The porosity of selected formations for deep underground waste injection ranged between 0.238 and 0.247 (average lower and upper value), and permeability ranged between 0.604 and $1.272 \mu \mathrm{m}^{2}$ (average lower and upper value), which is in line with the recommended values provided by Tables 5 and 6.

When the geological formations selected for underground waste slurry injection are analyzed based on depth, it can be concluded that, in one-third of the analyzed projects (in 33\% of the projects), the waste was injected in intervals between 1000 and $1500 \mathrm{~m}$, followed by intervals from 1500 to $2000 \mathrm{~m}(28 \%)$ and intervals from 500 to $1000 \mathrm{~m}(22 \%)$. Lower values were observed in intervals from 2000 to $2500 \mathrm{~m} \mathrm{(6 \% )} \mathrm{and} \mathrm{below} 500 \mathrm{~m}(11 \%)$ (Figure 8). This can be explained by technical and safety limitations. Injections in intervals deeper than $2500 \mathrm{~m}$ causes a significant increase in wellhead injection pressure as a consequence of the increased pressure drop, while injections in formations at depths lower than $500 \mathrm{~m}$ pose a security risk. 


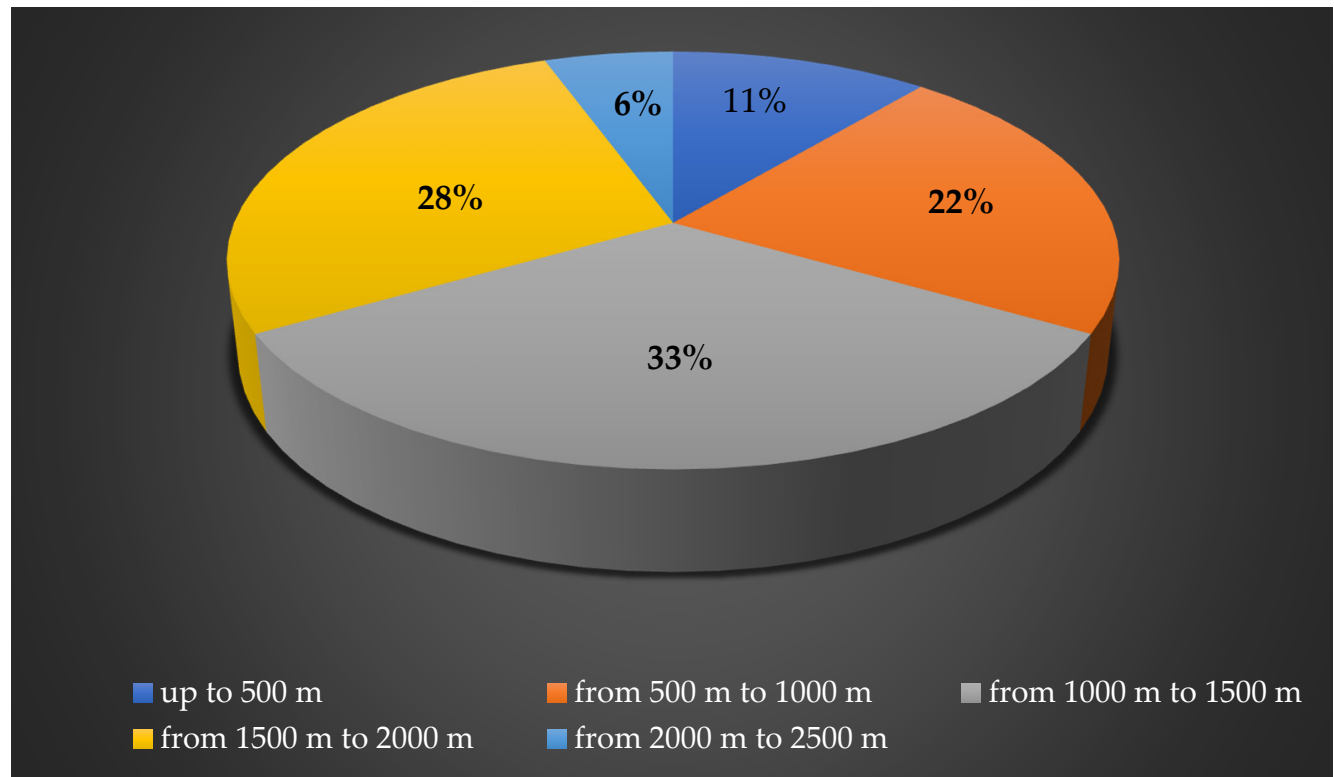

Figure 8. Distribution of injected formation depths (from Table 7).

The injected waste slurry in analyzed projects had solid (particles) portions between $12.2 \%$ and $22.3 \%$ by volume (average lower and upper value) and density between 1141 and $1262 \mathrm{~kg} / \mathrm{m}^{3}$ (average lower and upper value). Waste slurry flow rates are presented in Figure 9, and from the data collected, it can be concluded that, in $27 \%$ of projects, waste slurry was injected at a flow rate lower than $1000 \mathrm{~m}^{3}$ per day; in $26 \%$ of projects, waste was injected at flow rates between 1500 and $2000 \mathrm{~m}^{3}$ per day, in $21 \%$ of projects, at rates between 1000 and $1500 \mathrm{~m}^{3}$ per day, and in $16 \%$ of projects, the waste slurry flow rate was between 2500 and $3000 \mathrm{~m}^{3}$ per day. Waste slurry flow rates between 2000 and $2500 \mathrm{~m}^{3}$ per day and more than $3000 \mathrm{~m}^{3}$ per day were recorded in only $10 \%$ of projects (cummulative).

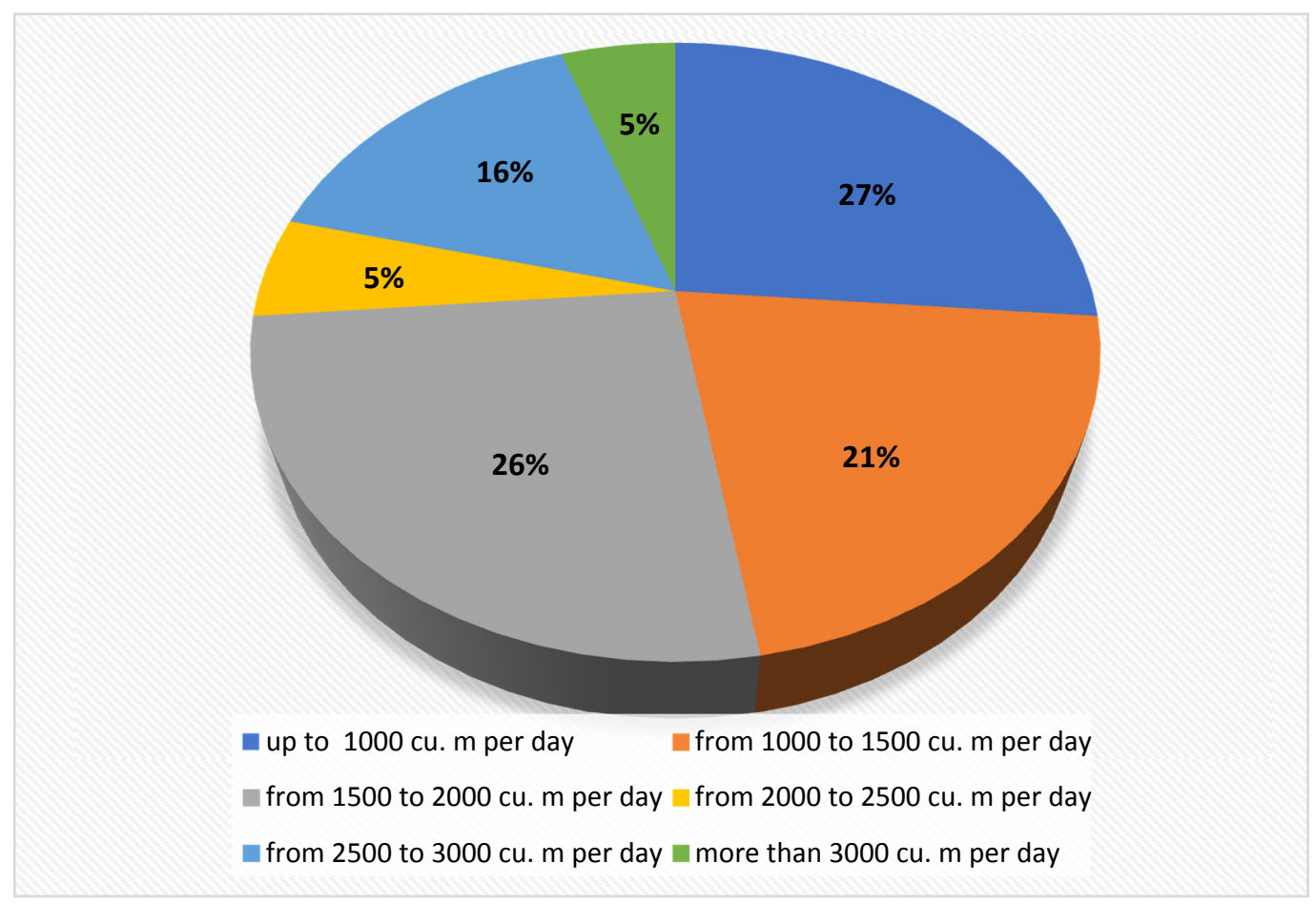

Figure 9. Waste slurry flow rates in analyzed projects (from Table 4). 
Also, in 16 of the 19 analyzed projects, deep underground waste slurry injections were conducted through tubing, as could be expected for safety, economic and technological reasons.

Despite well-known and proven technology, future progress is necessary in terms of better understanding disposal domain characterizations during the planning and execution phases. This includes using 3D simulators as well as real-time monitoring of injection parameters and continuous improvements of created disposal domain models and fracture networks. Only by continuously monitoring all parameters and through real-time visualization of disposal domains can the maximum volume of slurry waste be disposed in the safest and economically most efficient manner, without impacting the environment and the community.

Author Contributions: N.G.-M.-creation of the idea for the paper, writing, reviewing and editing of text related to waste injection technology and equipment and reviewing of the discussion and conclusion section, B.P.-writing and editing of text related to disposal domain characterizations, wellbore integrity, injection well plugging and abandonment and discussion section; P.M.--preparation of the comprehensive literature overview of the past and ongoing deep underground slurry waste injection projects and preparation of the tables and diagrams and I.M.- preparation of the comprehensive literature overview of the past and ongoing deep underground slurry waste injection projects and preparation of tables and diagrams. All authors have read and agreed to the published version of the manuscript.

Funding: This research received no external funding.

Conflicts of Interest: The authors declare no conflicts of interest.

\section{References}

1. Onwukwe, S.I.; Nwakaudu, M.S. Drilling Waste Generation and Management Approach. Int. J. Environ. Sci. Dev. 2012, 3, 252-257. [CrossRef]

2. Shokanov, T.A.; Nolte, K.G.; Fragachán, F.E.; Ovalle, A.; Geehan, T. Waste Subsurface Injection: Pressure Injection and Decline Analysis. In Proceedings of the SPE Hydraulic Fracturing Technology Conference, College Station, TX, USA, 29-31 January 2007. [CrossRef]

3. Kholy, S.M.; Sameh, O.; Mounir, N.; Shams, M.; Mohamed, I.M.; Abou-Sayed, A.; Abou-Sayed, O. Evaluating the Feasibility of Waste Slurry Injection in an Oil Prospect in the Western Desert, Egypt. In Proceedings of the SPE Middle East Oil and Gas Show and Conference, Manama, Bahrain, 18-21 March 2019. [CrossRef]

4. Matanović, D.; Gaurina-Međimurec, N. Environmental Aspects of Waste Generation and Disposal in Petroleum Engineering. In Proceedings of the 9th Conference on Sustainable Development of Energy, Water and Environment Systems, Venice, Italy; Istanbul, Turkey, 20-27 September 2014; paper SDEWES2014-0327.

5. Bruno, M.S.; Qian, H.X. Economic Disposal of Solid Oilfield Wastes. JPT 1995, 47, 775. [CrossRef]

6. Getliff, J.M.; Silverstone, M.P.; Sharman, A.K.; Lenn, M.; Hayes, T. Waste Management and Disposal of Cuttings and Drilling Fluid Waste Resulting from the Drilling and Completion of Wells to Produce Orinoco Very Heavy Oil in Eastern Venezuela. In Proceedings of the SPE International Conference on Health, Safety and Environment in Oil and Gas Exploration and Production, Caracas, Venezuela, 7-10 June 1998. [CrossRef]

7. Cline, J.T.; Piper, W.A. Drilling Waste Controls. In Proceedings of the Second International Conference on Health, Safety \& Environment Oil \& Gas Exploration and Production, Jakarta, Indonesia, 25-27 January 1994; pp. 573-581. [CrossRef]

8. Veil, J.A. Drilling Waste Management: Past, Present and Future. In Proceedings of the SPE Annual Technical Conference and Exhibition, San Antonio, TX, USA, 29 September-2 October 2002. [CrossRef]

9. McKay, M.; Seward, M.W.; Smith, G.; Brady, S.J. Minimizing Drilling Fluid Waste Discharges While Drilling an Arctic Exploratory Well. In Proceedings of the Western Regional Meeting, Long Beach, CA, USA, 20-22 March 1991. [CrossRef]

10. Arfie, M.; Marika, E.; Purbodiningrat, E.S.; Woodard, H.A. Implementation of Slurry Fracture Injection Technology for E\&P Wastes at Duri Oilfield. In Proceedings of the SPE Asia Pacific Health, Safety and Environment Conference and Exhibition, Kuala Lumpur, Malaysia, 19-20 September 2005. [CrossRef]

11. Gaurina-Međimurec, N. Waste Disposal Methods in Petroleum Engineering. In Annual 2002 of the Croatian Academy of Engineering; Croatian Academy of Engineering: Zagreb, Croatia, 2002; pp. 35-49. 
12. Gaurina-Međimurec, N.; Matanović, D.; Simon, K. Oil Field Waste Disposal Methods. In Transactions of the VŠB-Technical University Ostrava, Mining and Geological Series, Monograph 15. 51; Technical University Ostrava, Faculty of Mining and Geology: Ostrava, Czech, 2005; Volume 1, pp. 67-70.

13. Susich, M.L.; Schwenne, M.W. Onshore Drilling Waste Management: Beneficial Reuse of Cuttings. In Proceedings of the Seventh SPE International Conference on Health, Safety and Environment in Oil and Gas Exploration and Production, Calgary, AB, Canada, 29-31 March 2004. [CrossRef]

14. Gaurina-Međimurec, N. The Environmental Impact of Drilling and Production Operations. In Proceedings of the 4th International Scientific-Professional Consultation "Energetic and Process Plants", Dubrovnik, Croatia, 24-26 May 2000; pp. 631-636.

15. Mokhalalati, T.; Al-Suwaidi, A.; El-Fatah Hendi, A. Managing Onshore Drilling Waste-Abu Dhabi Experience. In Proceedings of the 9th Abu Dhabi International Petroleum Exhibition and Conference, Abu Dhabi, UAE, 15-18 October 2000. [CrossRef]

16. Okorodudu, A.; Akinbodunse, A.; Linden, L.; Anwuri, L.; Irrechukwu, D.O.; Zagi, M.M.; Guerrero, H. Feasibility Study of Cuttings-Injection Operation: A Case Study of the Niger Delta Basin. In Proceedings of the SPE International Conference on Health, Safety and Environment in Oil and Gas Exploration and Production, Abu Dhabi, UAE, 2-4 April 2006. [CrossRef]

17. Gogan, R.; Vencenzo, M.; Ayapbergenov, Y. Waste Management for Drillers. In Proceedings of the SPE Caspian Carbonates Technology Conference, Atyrau, Kazakhstan, 8-10 November 2010. [CrossRef]

18. Reed, A.C.; Mathews, J.L.; Bruno, M.S.; Olmstead, S.E. Safe Disposal of One Million Barrels of NORM in Louisiana Through Slurry Fracture Injection. SPE Drill. Complet. 2002, 17, 72-81. [CrossRef]

19. Guo, Q.; Abou-Sajed, A.S. World Drill Cuttings Injection Permitting Requirements and Guidelines. In Proceedings of the SPE/EPA/DOE Exploration and Production Environmental Conference, San Antonio, TX, USA, 10-12 March 2003. [CrossRef]

20. Bruno, M.S. Slurry Fracture Injection of Petroleum and Municipal Sanitation Wastes. In Proceedings of the 5th Asian Rock Mechanics Symposium (ARMS5), Teheran, Iran, 24-26 November 2008; pp. 51-58.

21. Sipple-Srinivasan, M.; Bruno, M.S.; Bilak, R.A.; Danyluk, P.G. Field Experiences with Oilfield Waste Disposal Through Slurry Fracture Injection. In Proceedings of the 67th Annual Western Regional Meeting of the SPE, Long Beach, CA, USA, 23-27 June 1997. [CrossRef]

22. Bruno, M.; Reed, A.; Olmstead, S. Environmental Management, Cost Management and Asset Management for High-Volume Oil Field Waste Injection Projects. In Proceedings of the IADC/SPE Drilling Conference, New Orleans, LA, USA, 23-25 February 2000. [CrossRef]

23. Guo, Q.; Geehan, T.; Ovalle, A. Increased Assurance of Drill Cuttings Reinjection: Challenges, Recent Advances, and Case Studies. SPE Drill. Complet. 2007, 22, 99-105. [CrossRef]

24. Gaurina-Međimurec, N.; Krištafor, Z. Waste Disposal Methods Applied in Croatia. In Proceedings of the Third International Symposium Mining and Environmental Protection, MEP 01, Vrdnik, Serbia, 21-23 May 2001; pp. 314-321.

25. Willson, S.M.; Steiger, R.P.; Moschovidis, Z.A.; Abou-Sayed, A.S.; de Bree, P.; Sirevåg, G. Laboratory Investigation of Drill Cuttings Disposal by Downhole Injection. In Rock Mechanics for Industry; Amadei, B., Kranz, R.L., Scott, G.A., Smeallie, P.H., Eds.; Balkema: Rotterdam, The Netherlands, 1999.

26. Fragachán, F.E.; Shokanov, T.A.; Ovalle, A.P.; Nolte, K.G. Mitigating Risks from Waste Subsurface Pressure Injection and Decline Analysis. In Proceedings of the SPE E\&P Environmental and Safety Conference, Galveston, TX, USA, 5-7 March 2007. [CrossRef]

27. Ovalle, A.; Ronderos, J.; Benelkadi, S.; Gumarov, S.; Simmons, S. Improved Waste Injection Monitoring and Modified Operational Procedures: The Key to Prolong Well Storage Capacity. In Proceedings of the SPE Middle East Oil \& Gas Show and Conference, Bahrain International Exhibition Centre, Manama, Bahrain, 15-18 March 2009. [CrossRef]

28. Puder, M.G.; Veil, J.A. Options and Costs for Off-Site Disposal of Oil and Gas Exploration and Production Wastes. In Proceedings of the SPE E\&P Environmental and Safety Conference, Galveston, TX, USA, 5-7 March 2007. [CrossRef]

29. Zoveidavianpoor, M.; Samsuri, A.; Shadizadeh, S.R. Chapter 17-Overview of Environmental Management by Drill Cutting Re-injection through Hydraulic Fracturing in Upstream Oil and Gas Industry. In Sustainable Development_-Authoritative and Leading Edge Content for Environmental Management; Ćurković, S., Ed.; In Tech: Rijeka, Croatia, 2012; pp. 389-410. [CrossRef] 
30. Gaurina-Međimurec, N. Underground Injection of Oil Field Waste. In Handbook of Research on Advancements in Environmental Engineering; Engineering Science Reference (An Imprint of IGI Global): Hershey, PA, USA, 2015; pp. 400-437.

31. Marinello, S.A.; Lyon, F.L.; Ballantine, W.T. Disposal of E\&P Waste by Injection: An Assessment of Technology and Regulatory Impacts. In Proceedings of the SPE/EPA/DOE Exploration and Production Environmental Conference, San Antonio, TX, USA, 26-28 February 2001. [CrossRef]

32. Abou-Sayed, A.S.; Guo, Q.; Meng, F.; Zaki, K. Ultimate Capacity of a Disposal Well in Drilling Waste Injection Operations. In Proceedings of the SPE/IADC Drilling Conference, Amsterdam, The Netherlands, 19-21 February 2003. [CrossRef]

33. Gumarov, S.; Ovalle, A.P.; Shokanov, T.A.; Park, G.; Simmons, S.L. Evaluation of Extended Seawater Injections Impact on Waste Injection Pressure Response and Waste Disposal Capacity. In Proceedings of the EUROPEC/EAGE Conference and Exhibition, Amsterdam, The Netherlands, 8-11 June 2009. [CrossRef]

34. Newman, K.; Woolsey, G.; McCosh, K.; Hand, E.; Boodhai, M. Multistage Centrifugal Pumps for Drilling and Production Waste Injection Operations. In Proceedings of the SPE Asia Pacific Health, Safety, Security and Environment Conference and Exhibition, Jakarta, Indonesia, 4-6 August 2009. [CrossRef]

35. Keck, R.G. Drill Cuttings Injection: A Review of Major Operations and Technical Issues. In Proceedings of the SPE Annual Technical Conference and Exhibition, San Antonio, TX, USA, 29 September-2 October 2002. [CrossRef]

36. Ji, L.; Gumarov, S.; Shokanov, T.; Anokhin, V.; Ronderos, J. Evaluating Wellbore Displacement Efficiency of Post-Slurry Overflushing and Its Effect on Injection Pressure in Waste Injection Operations. In Proceedings of the International Petroleum Technology Conference, Beijing, China, 26-28 March 2013. [CrossRef]

37. Dusseault, M.B.; Bolak, R.A.; Rodwell, L.G. Disposal of Dirty Liquids using Slurry Fracture Injection. In Proceedings of the SPE/EPA Exploration and Production Environmental Conference, Dallas, TX, USA, 3-5 March 1997. [CrossRef]

38. Ronderos, J.R.; Ovalle, A.P. Geomechanical Modeling Techniques Applied to Waste Injection Process. In Proceedings of the 44th US Rock Mechanics Symposium and 5th US-Canada Rock Mechanics Symposium, Salt Lake City, UT, USA, 27-30 June 2010.

39. Fragachán, F; Ovalle, A.; Shokanov, T. Pressure Monitoring: Key for Waste Management Injection Assurance. In Proceedings of the First International Oil Conference and Exhibition in Mexico, Cancun, Mexico, 31 August-2 September 2006. [CrossRef]

40. Louviere, R.J.; Reddoch, J.A. Onsite Disposal of Rig-Generated Waste Via Slurrification and Annular Injection. In Proceedings of the SPE/IADC Drilling Conference, Amsterdam, The Netherlands, 23-25 February 1993. [CrossRef]

41. Guo, Q.; Abou-Sayed, A.S.; Engel, H.R. Feeling the Pulse of Drill Cuttings Injection Wells-A Case Study of Simulation, Monitoring and Verification in Alaska. SPE J. 2007, 458-467. [CrossRef]

42. Gaurina-Međimurec, N.; Matanović, D.; Krištafor, Z. Injection of Drilling Wastes in Dry Hole. In Proceedings of the International Conference "Special Methods of Deposit Utilization", Ostrava, Czech Republic, 12-13 November 1998; pp. 87-94.

43. Gaurina-Međimurec, N.; Krištafor, Z.; Matanović, D.; Kulenović, I.; Gospić-Miočev, D. Subsurface disposal of technological waste-Present and future in Croatia. Nafta 1999, 50, 279-283.

44. Gaurina-Međimurec, N.; Pašić, B.; Medved, I.; Mijić, P. Drilling Waste Injection. In Proceedings of the 7th International Symposium on Mining and Environmental Protection-MEP 19, Vrdnik, Serbia, 25-28 September 2019; Ristović, I., Ed.; pp. 56-62.

45. Krištafor, Z.; Gaurina-Međimurec, N.; Matanović, D. Well Design for Subsurface Injection of Drilling and Industrial Liquid Waste. In Proceedings of the International Congress "Energy and Environment", Opatija, Croatia, 28-30 October 1998; Volume I, pp. 307-314.

46. Maliardi, A.; Cecconi, F.; Simeone, D.; Gumarov, S.; Shokanov, T.; Anokhin, V.; Benelkadi, S.; Bosisio, F.; Mangiameli, R. Subsurface Cuttings Injection: Technical Challenges and Opportunities. In Proceedings of the International Petroleum Conference, Doha, Qatar, 19-22 January 2014. [CrossRef]

47. Fristoe, B.R. Drilling Wastes Management for Alaska's North Slope. In Proceedings of the International Arctic Technology Conference, Anchorage, AK, USA, 29-31 May 1991. [CrossRef]

48. Minton, R.C.; Secoy, B. Annular Re-Injection of Drilling Wastes. J. Pet. Technol. 1993, 45, 1081-1085. [CrossRef] 
49. Alba, A.; Fragachán, F.; Ovalle, A.; Shokanov, T. Environmentally Safe Waste Disposal: The Integration of Cuttings Collection, Transport and Reinjection. In Proceedings of the International Oil Conference and Exhibition, Veracruz, Mexico, 27-30 June 2007. [CrossRef]

50. Fetsenets, R.M.; Ovalle, A.; Still, V.; Blyus, D.; Shokanov, T.; Anokhin, V. Meeting the Challenges of Waste Disposal in the Mainland of Russia-Successful Design and Implementation of the First Full-Scale Drilling Waste Injection Project in Western Siberia. In Proceedings of the SPE/IADC Middle East Drilling Technology Conference \& Exhibition, Manama, Bahrain, 26-28 October 2009. [CrossRef]

51. Shokanov, T.; Gumarov, S.; Ronderos, J.; Fragachan, F.E. Multiple-Fracture Propagation, Orientation and Complexities in Drilling Waste Injection. In Proceedings of the SPE Hydraulic Fracturing Technology Conference and Exhibition, The Woodlands, TX, USA, 24-26 January 2011. [CrossRef]

52. Gogan, R.; Mattia, V.; Oates, M.; Gumarov, S.; Shokanov, T.; Mangiameli, R.; Simmons, S.; Boyles, G.; Woolsley, G. Cuttings Re-Injection as an Environmentally Safe and Economically Efficient Drilling Waste Management Option for Karachaganak Field. In Proceedings of the SPE Caspian Carbonates Technology Conference, Atyrau, Kazakhstan, 8-10 November 2010. [CrossRef]

53. Cobb, M.; Irvine, M.; Fichera, M. Midia Gas Development, Drill Cuttings Disposal—Best Practicable Environmental Option; ERM Project No. 0497814; ERM: London, UK, April 2019.

54. Bartko, K.; Al-Shobaili, Y.; Gagnard, P.; Warlick, M.; Im, A.B. Drill Cuttings Re-Injection (CRI) Assessment for the Manifa Field: An Environmentally Safe and Cost-Effective Drilling Waste Management Strategy. In Proceedings of the SPE Saudi Arabia Section Technical Symposium and Exhibition, AlKhobar, Saudi Arabia, 9-11 May 2009. [CrossRef]

55. Onaisi, A.; Po, V.; Lutfalla, H. Learning from Three Years Annular Injection of Drill Wastes in Alwyn and Dunbar Fields in the North Sea. In Proceedings of the 11th Abu Dhabi International Petroleum Exhibition and Conference, Abu Dhabi, UAE, 10-13 October 2004. [CrossRef]

56. Moschovidis, Z.; Steiger, R.; Peterson, R.; Warpinski, N.; Wright, C.; Chesney, E.; Hagan, J.; Abou-Sayed, A.; Keck, R.; Frankl, M.; et al. The Mounds Drill-Cuttings Injection Field Experiment: Final Results and Conclusions. In Proceedings of the IADC/SPE Drilling Conference, New Orleans, LA, USA, 23-25 February 2000. [CrossRef]

57. Guo, Q.; Geehan, T.; Ullyott, K.W. Formation Damage and Its Impacts on Cuttings-Injection-Well Performance: A Risk Based Approach on Waste-Containment Assurance. In Proceedings of the SPE International Symposium and Exhibition on Formation Damage, Lafayette, LA, USA, 15-17 February 2006. [CrossRef]

58. Zaki, K.S.; Kristiansen, T.G.; Abou-Sayed, A.S.; Summers, C.W.; Wang, G.G.; Sarfare, M.D. Geo-mechanics of Bach Injections in Horizontal Waste Disposal Wells-North Sea. In Proceedings of the 40th U. S. Symposium on Rock Mechanics (USRMS): Rock Mechanics for Energy, Mineral and Infrastructure Development in Northern Regions, Anchorage, AK, USA, 25-29 June 2005.

59. Mahrous, R.; Tsoy, V.; Ellis, R. Customized High-Rate Cuttings Reinjection System: Effective Design Maintains Continuous Zero Discharge Operations on Sakhalin Island. In Proceedings of the SPE/IADC Drilling International Conference and Exhibition, The Hague, The Netherlands, 5-7 March 2019. [CrossRef]

60. Mohamed, I.M.; Abou-Sayed, O.; Abou-Sayed, A.S.; Algarhy, A.; Elkatatny, S.M. Guidelines to Define the Critical Injection Flow Rate to Avoid Formation Damage During Slurry Injection into High Permeability Sandstone. Eng. Fract. Mech. 2018, 200, 208-217. [CrossRef]

61. Guo, Y.; Mohamed, I.M.; Abou-Sayed, O.; Abou-Sayed, A. Injection and Remote Real-Time Monitoring: Slurry Injection Case Study. In Proceedings of the SPE Annual Technical Conference and Exhibition, San Antonio, TX, USA, 9-11 October 2017. [CrossRef]

62. Romero, L.; Ramirez, O.; Hernandez, R.; Bastidas, A. First Successful Cuttings Reinjection CRI Operation in Ecuador: An Alternative to Help Minimize the Environmental Impact in a Protected Area. In Proceedings of the Abu Dhabi International Petroleum Exhibition \& Conference, Abu Dhabi, UAE, 7-10 November 2016. [CrossRef]

63. Mehtar, M.; Haddad, M.; Toki, T.; Gumarov, S.; Benelkadi, S.; Shokanov, T.; Vizzini, C.; Mitchell, C.; Khudorozhkov, P. Feed to Execution: First Successful Hydraulic Fracture Cuttings Re-Injection Process Offshore Abu Dhabi. In Proceedings of the Abu Dhabi International Petroleum Exhibition \& Conference, Abu Dhabi, UAE, 7-10 November 2016. [CrossRef] 
64. Xia, G.; Bilak, R.; Marika, E.; Al-Shehri, H.A.; Al-Qahtani, F.Y. Performance Assessment of Cuttings Re-Injection (CRI) Operations at the Manifa Oil Field, KSA. In Proceedings of the Rock Mechanics for Natural Resources and Infrastructure, ISRM Specialized Conference, Goiania, Brazil, 9-13 September 2014.

65. Kunze, K.R.; Romer, E.E.; Duck, S. Colorado Drill Cuttings Injection Pilot Results. In Proceedings of the IADC/SPE Drilling Conference and Exhibition, San Diego, CA, USA, 6-8 March 2012. [CrossRef]

66. Ovalle, A.; Shokanov, T.; Simmons, S.; Ronderos, J. Field Implementation of Sub-Surface Waste Injection: An Integrated Approach for Field Disposal Perspective. In Proceedings of the IADC/SPE Asia Pacific Drilling Technology Conference and Exhibition, Jakarta, Indonesia, 25-27 August 2008. [CrossRef]

67. Reed, A.C.; Mathews, J.L.; Bruno, M.S.; Olmstead, S.E. Safe Disposal of One Million Barrels of NORM in Louisiana Through Slurry Fracture Injection. In Proceedings of the SPE Annual Technical Conference and Exhibition, New Orleans, LA, USA, 30 September-3 October 2001. [CrossRef]

68. Sipple-Srinivasan, M.M.; Bruno, M.S.; Hejl, K.A.; Danyluk, P.G.; Olmstead, S.E. Disposal of Crude Contaminated Soil Through Slurry Fracture Injection at the West Coyote Field in California. In Proceedings of the SPE Western Regional Meeting, Bakersfield, CA, USA, 10-13 May 1998. [CrossRef]

69. Moschovidis, Z.A.; Gardner, D.C.; Sund, G.V.; Veatch, R.W., Jr. Disposal of Oily Cuttings by Downhole Periodic Fracturing Injections, Valhall, North Sea: Case Study and Modeling Concepts. In Proceedings of the SPE/IADC Drilling Conference, Amsterdam, The Netherlands, 22-25 February 1994. [CrossRef]

70. Willson, S.M.; Rylance, M.; Last, N.C. Fracture Mechanics Issues Relating to Cuttings Re-Injection at Shallow Depth. In Proceedings of the SPE/IADC Drilling Conference, Amsterdam, The Netherlands, 23-25 February 1993. [CrossRef]

71. Abou-Sayed, A.S.; Andrews, D.E.; Buhidma, I.M. Evaluation of Oily Waste Injection Below the Permafrost in Prudhoe Bay Field. In Proceedings of the SPE California Regional Meeting, Bakersfield, CA, USA, 5-7 April 1989. [CrossRef]

72. Nadeem, M.; Dusseault, M.B.; Bilak, R.A. Assessment Criteria for Deep Waste Disposal Sites. In Proceedings of the 40th US Symposium on Rock Mechanics (USRMS), Anchorage, AK, USA, 25-29 June 2005.

73. Nadeem, M.; Dusseault, M.B. Geological Engineering Criteria for Deep Solids Injection. Environ. Geosci. 2007, 14, 61-77. [CrossRef]

74. Saif ud Din, S.; Reza Oskui, G.P.; Al-Dousari, A.; Al Ghadban, A.N.; Al Murad, M. An Environmentally Viable Waste Disposal Method for Oil-producing Countries. Waste Manag. Res. 2009, 28, 169-176. [CrossRef] [PubMed]

75. Ferguson, G.; McIntosh, J.C.; Perrone, D.; Jasechko, S. Competition for Shrinking Window of Low Salinity Groundwater. Environ. Res. Lett. 2018, 13,1-9. [CrossRef]

76. Baker, B.D.; Rieke, H.H. A Balanced Approach to Waste Disposal using UFI (Underground Fracture Injection). In Proceedings of the SPE Annual Technical Conference and Exhibition, New Orleans, LA, USA, 30 September-3 October 2001. [CrossRef]

77. Shokanov, T.A.; Fragachán, F.E.; Feyereisen, S.B.; Greener, J.M. Mitigating Risks from Waste Subsurface Injection through Accurate Downhole Pressure Measurement, Analysis, and Fracture Monitoring. In Proceedings of the IADC/SPE Drilling Conference, Orlando, FL, USA, 4-6 March 2008. [CrossRef]

78. Ji, L.; Shokanov, T.A.; Fragachan, F.E.; Ovalle, A.; Ronderos, J. Multi-Fracture Complexities in Drilling Waste Injection: Wagon-Wheel Uniform Disposal Domain or Secondary Fracture Branching. In Proceedings of the 43rd US Rock Mechanics Symposium and 4th US-Canada Rock Mechanics Symposium, Asheville, NC, USA, 28 June-1 July 2009.

79. Shokanov, T.; Still, V.; Hernandez, E.; Anokhin, V.; Ovalle, A.; Fragachán, F. Subsurface Drilling Waste Injection: Real-Time Waste Domain Characterization Using Injection Monitoring and Pressure Interpretation. In Proceedings of the SPE Russian Oil \& Gas Technical Conference and Exhibition, Moscow, Russia, 28-30 October 2008. [CrossRef]

80. Thornhill, J.T.; Benefield, B.G. Detecting Water Flow Behind Pipe in Injection Wells; EPA/600/R-92/041; United States Environmental Protection Agency: Washington, DC, USA, February 1992.

81. Gaurina-Međimurec, N.; Pašić, B. Design and Mechanical Integrity of $\mathrm{CO}_{2}$ Injection Well. In Mining-Geological-Petroleum Engineering Bulletin; Faculty of Mining, Geology and Petroleum Engineering: Zagreb, Croatia, 2011; Volume 23, pp. 1-8. 
82. Shen, X.; Shen, G.; Standifird, W. Numerical Calculation of Fault Reactivation and Resultant Seismic Behavior Related to Cuttings Reinjection in Offshore West Africa. In Proceedings of the 49th US Rock Mechanics/Geomechanics Symposium, San Francisco, CA, USA, 28 June-1 July 2015.

83. Lele, S.P.; Tyrrell, T.; Dasari, G.R. Geomechanical Analysis of Fault Reactivation due to Hydraulic Fracturing. In Proceedings of the 51st US Rock Mechanics/Geomechanics Symposium, San Francisco, CA, USA, 25-28 June 2017.

84. Liu, K.; Dahi Taleghani, A.; Gao, D. Semianalytical Model for Fault Slippage Resulting from Partial Pressurization. SPE J. 2019, 1-14. [CrossRef]

85. Cappa, F.; De Barros, L.; Wynants-Morel, N.; Guglielmi, Y.; Birkholzer, J. From Aseismic Slip to Seismicity During Fluid Injection Controlled by Interactions Between Stress Perturbation, Permeability Increases and Fault Structure. In Proceedings of the 53rd US Rock Mechanics/Geomechanics Symposium, New York, NY, USA, 23-26 June 2019.

86. Haddad, M.; Eichhubl, P. Poroelastic Models for Fault Reactivation in Response to Injection and Production. In Proceedings of the 52nd US Rock Mechanics/Geomechanics Symposium, Seattle, WA, USA, 17-20 June 2018.

87. Bakhshian, S.; Dashtian, H.; Paiaman, A.M.; Al-Anazi, B.D. A Review on Impacts of Drilling Mud Disposal on Environment and Underground Water Resources in South of Iran. In Proceedings of the SPE/IADC Middle East Drilling Technology Conference \& Exhibition, Manama, Bahrain, 26-28 October 2009. [CrossRef]

88. Booz, Allen and Hamilton Inc. Development of Procedures and Costs for Proper Abandonment and Plugging of Injection Wells; 68-01-5971; Prepared for the U. S. Environmental Protection Agency: Washington, DC, USA, 30 April 1980.

(C) 2020 by the authors. Licensee MDPI, Basel, Switzerland. This article is an open access article distributed under the terms and conditions of the Creative Commons Attribution (CC BY) license (http://creativecommons.org/licenses/by/4.0/). 